\title{
Birds and Mammals of Coats Island, N.W.T.
}

\author{
ANTHONY J. GASTON ${ }^{1}$ and HENRI OUELLET ${ }^{2}$
}

\author{
(Received 21 June 1996; accepted in revised form 21 January 1997)
}

\begin{abstract}
We summarize records of birds and mammals obtained at Coats Island, Northwest Territories during one visit by a National Museum of Natural Sciences expedition and fourteen visits by Canadian Wildlife Service field crews to the northeast corner of the island, as well as records obtained from the journals of the Hudson's Bay Company post active on the island from 1920 to 1924 . The terrestrial mammal fauna is very depauperate, lacking any small herbivores. Consequently, predators specializing in small mammals — such as ermine, snowy owl, and long-tailed jaeger, all common on nearby Southampton Island-are rare or absent from Coats Island, except in passage. In addition, there are no snow goose colonies on Coats Island, although good numbers of Canada geese breed there, and some brant may also do so. This means that grazing on the island is mainly confined to the resident caribou population. The absence of small mammals and the relatively low density of geese may have accounted for the poor results of fox trapping during the period when the Hudson's Bay Company post was operating. Numbers of most marine mammals appear to have changed little since the 1920s, although bowhead whales may have become rarer, with only two sightings since 1981, compared to several annually in the 1920s. Winter records from the 1920-24 post journals suggest that waters off Coats Island are within the wintering range of beluga, walrus, and thick-billed murres. Eighty-four species of birds have been seen since 1975; this number includes many sightings of vagrant birds well outside their normal ranges. This may be accounted for by the comparative lushness of the vegetation surrounding the thick-billed murre colony, which attracts birds from long distances.
\end{abstract}

Key words: Coats Island, birds, mammals, distribution

RÉSUMÉ. On a fait un sommaire des relevés d'oiseaux et de mammifères obtenus à l'île Coats (Territoires du Nord-Ouest) durant la visite d'une expédition du Musée national des sciences naturelles et 14 visites effectuées par des équipes de terrain du Service canadien de la faune dans l'angle nord-est de l'île, ainsi que des relevés provenant des livres du comptoir de la Compagnie de la baie d'Hudson, qui était en activité dans l'île entre 1920 et 1924. La faune des mammifères terrestres est extrêmement démunie, ne comptant aucun petit herbivore. Cela explique que les prédateurs spécialisés dans les petits mammifères comme l'hermine, le harfang des neiges et le labbe à longue queue-tous communs dans l'île de Southampton avoisinante-soient rares ou absents dans l'île Coats, sauf de façon transitoire. Il n'y a en outre pas de colonies d'oies des neiges dans cette île, bien que nombre de bernaches du Canada s'y reproduisent et peut-être quelques bernaches cravants. Cela signifie que l'herbe est surtout broutée par la population locale des caribous. L'absence de petits mammifères et la densité relativement faible des oies pourraient expliquer les piètres résultats du piégeage du renard au cours de la période d'activité du comptoir de la Compagnie de la baie d'Hudson. Pour la plupart des mammifères marins, le nombre semble n'avoir que peu changé depuis les années 1920, bien que la baleine boréale soit devenue plus rare, ayant fait l'objet de seulement deux observations depuis 1981 en comparaison de plusieurs par an dans les années 1920. Les livres du comptoir qui portent sur les hivers de 1920 à 1924 suggèrent que les eaux au large de l'île Coats sont situées à l'intérieur les limites du territoire hivernal du bélouga, du morse et de la marmette de Brünnich. Depuis 1975, on a aperçu 84 espèces d'oiseaux, comprenant toutefois de nombreuses espèces vagabondes totalement en dehors de leur territoire normal. Ce phénomène peut s'expliquer par la richesse comparative de la végétation entourant la colonie de marmettes de Brünnich, qui attire les oiseaux depuis de grandes distances.

Mots clés: île Coats, oiseaux, mammifères, répartition

Traduit pour la revue Arctic par Nésida Loyer.

\section{INTRODUCTION}

Coats Island, at the north end of Hudson Bay (Fig. 1), is the largest uninhabited island in the Northern Hemisphere south of the Arctic Circle. It is $130 \mathrm{~km}$ long and comprises $5600 \mathrm{~km}^{2}$ of mainly lowland tundra, reaching a maximum elevation of
$185 \mathrm{~m}$ above sea level (asl). Less than $5 \%$ of the island is more than $100 \mathrm{~m}$ asl. The underlying rocks are Precambrian metamorphics in the northeast and Palaeozoic sedimentary rocks, mainly limestone and sandstone, elsewhere (Heywood and Sandford, 1976). These are overlain in many areas by raised beach deposits dating from the Holocene and reaching

\footnotetext{
${ }^{1}$ Canadian Wildlife Service, National Wildlife Research Centre, 100 Gamelin Blvd., Hull, Quebec K1A 0H3, Canada;

Tony.Gaston@ec.gc.ca

${ }^{2}$ Canadian Museum of Nature, P.O. Box 3443, Station D, Ottawa, Ontario K1P 6P4, Canada, or Département de sciences

biologiques, Université de Montréal, C.P. 6128, Succ. Centre-Ville, Montréal, Québec H3C 3J7, Canada

(C) The Arctic Institute of North America
} 


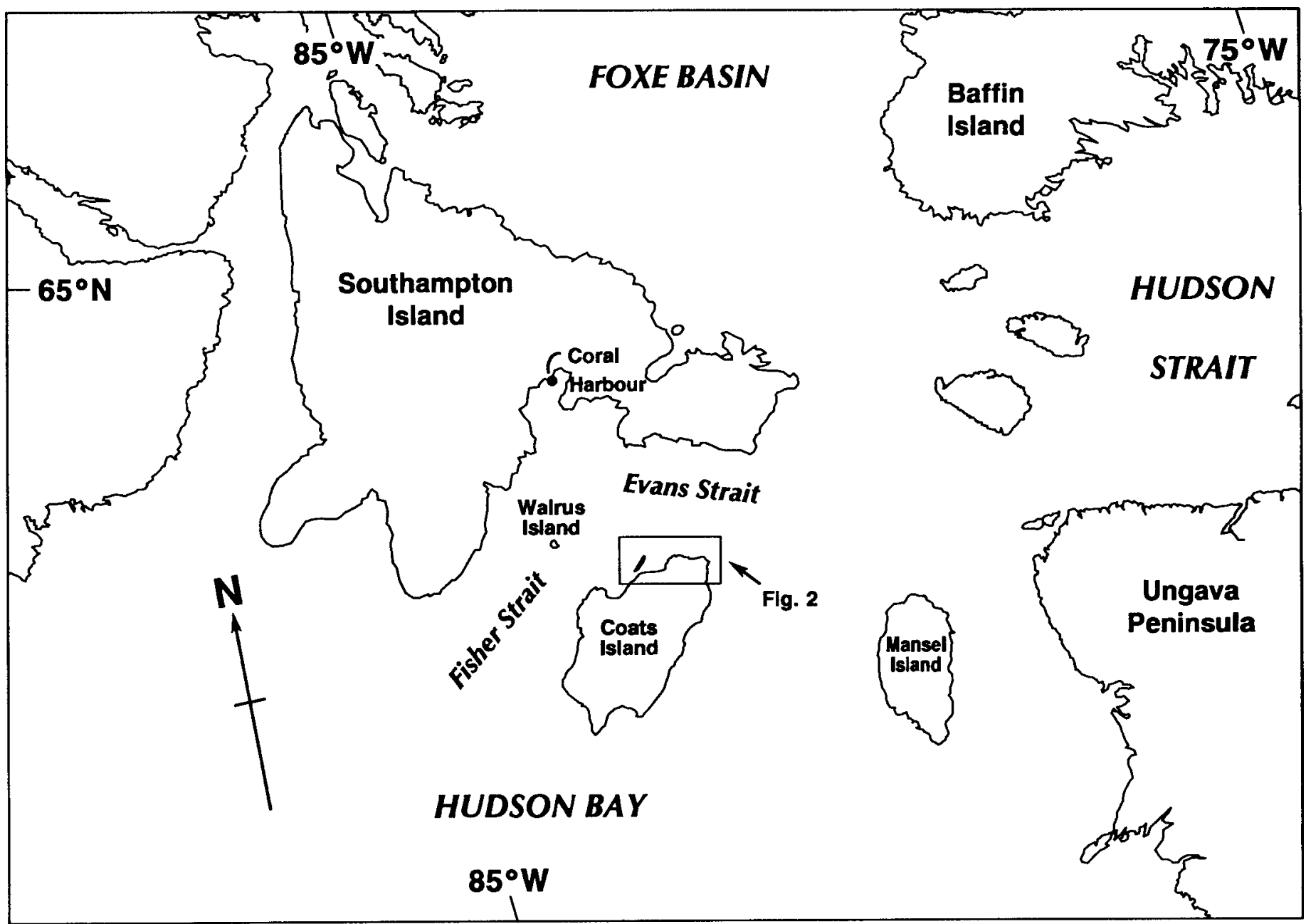

FIG. 1. Map of northern Hudson Bay, Northwest Territories, Canada

$124 \mathrm{~m}$ asl (Shilts, 1985). Consequently, most of Coats Island was submerged immediately after the decay of the Laurentide ice sheet. On Southampton Island, marine transgression fell below $100 \mathrm{~m}$ above current sea level about 5500 years ago (Dredge and Cowan, 1989). Assuming a similar timetable for Coats Island, most of the island has been available for colonization by terrestrial vertebrates for less than 6000 years.

The original human inhabitants of Coats Island, the Sadlermiut, were not contacted by Europeans until 1824 and had died out by the end of the 19th century (Bruemmer, 1969). A Hudson's Bay Company (HBC) trading post was maintained on the island from August 1920 to August 1924, and a number of Inuit families lived on the island during that period, some of whom had been brought from Baffin Island (HBC, 191824). Since the closure of the Hudson's Bay post, the island has been occupied sporadically for short periods by a few families from Coral Harbour, the nearest permanent community. The last overwintering on Coats Island was approximately 25 years ago (J. Nakoolak, pers. comm. 1994).

This paper is based largely on observations of birds and mammals recorded by teams from the National Museum of Natural Sciences (NMNS, now Canadian Museum of Nature) who visited Coats Island during the summer of 1975 and the Canadian Wildlife Service (CWS) who visited in the summers of 1981 and 1984-96 inclusive (Table 1). The Museum of Natural Sciences expedition was intended to undertake a basic survey of the breeding birds of the island and to collect a representative series of specimens for taxonomic studies. Personnel consisted of H. Ouellet, R.M. Poulin, and B.E. Lyon. The Canadian Wildlife Service project principally involved banding and monitoring thick-billed murres (Uria lomvia) that were breeding at the colony near Cape Pembroke (Fig. 2). Consequently, most observations involved birds and mammals seen within walking distance of the camp, situated close to the west murre colony, and were incidental to the work being carried out on thick-billed murres. Short visits were made to a lowland tundra area (the west hut area) $25 \mathrm{~km}$ west of the main camp on 26 July 1993, 15-19 July 1994, and 7-10 July 1995. This was the area where the last temporary settlement on Coats Island had been located.

Additional records of birds seen at sea within sight of Coats Island, on a visit to Walrus Island on 22 July 1993, and on a short trip to Bencas Island on 31 July 1995, are included, as well as notes made by the Hudson's Bay post managers in the post journals (HBC, 1918-24). Two individuals managed the post during its brief history: S.G. Ford from August 
TABLE 1. Dates of visits to Coats Island by National Museum of Natural Sciences (1975) and Canadian Wildlife Service (1981-96) teams.

\begin{tabular}{|c|c|c|c|}
\hline \multirow[t]{2}{*}{ Year } & \multicolumn{2}{|l|}{ Dates } & \multirow{2}{*}{ Personnel } \\
\hline & Northeast area & West hut area & \\
\hline 1975 & 21-27 July & & $\mathrm{HO}, \mathrm{RP}, \mathrm{BL}, \mathrm{WG}$ \\
\hline 1981 & $9-18$ August & & $\mathrm{AG}, \mathrm{SS}$ \\
\hline 1984 & 5-18 August & & $\mathrm{AG}, \mathrm{RE}, \mathrm{CH}$ \\
\hline 1985 & 27 July-11 August & & $\mathrm{RE}, \mathrm{SW}, \mathrm{DN}, \mathrm{JG}, \mathrm{AE}$ \\
\hline 1986 & 22 July-10 August & & $\mathrm{AG}, \mathrm{DN}, \mathrm{JG}, \mathrm{DD}$ \\
\hline 1987 & 23 July-18 August & & $\mathrm{RE}, \mathrm{DN}, \mathrm{DC}, \mathrm{KB}, \mathrm{JG}$ \\
\hline 1988 & 9 June-17 August & & DN, SJ, KA, AG, CR, DC, EM \\
\hline 1989 & 27 July-20 August & & AG, DC, GG, LD, \\
\hline 1990 & 23 May-24 August & & $\mathrm{AG}, \mathrm{DN}, \mathrm{AB}, \mathrm{GG}, \mathrm{MP}, \mathrm{LD}, \mathrm{TA}$ \\
\hline 1991 & 4 June-29 August & & $\mathrm{AG}, \mathrm{GG}, \mathrm{LD}, \mathrm{TA}, \mathrm{MP}, \mathrm{GD}$ \\
\hline 1992 & 6 June-24 August & & $\begin{array}{l}\text { GG, MH, TA, MP, AG, PP, GD, } \\
\text { SP }\end{array}$ \\
\hline 1993 & 15 July-21 August & 26 July & $\mathrm{AG}, \mathrm{CE}, \mathrm{MH}, \mathrm{JN}, \mathrm{EH}, \mathrm{IS}, \mathrm{GD}$ \\
\hline 1994 & 9 June-30 August & $15-19$ July & AG, KK, MH, JN, CE, KL, LP \\
\hline 1995 & 3 June-10 September & 7-10 July & GG, MH, JN, GB, KL, CJ, AG \\
\hline 1996 & 25 May -25 August & & $\begin{array}{l}\text { GG, AG, JN, MP, SD, CK, GI, } \\
\text { CJ, GGi }\end{array}$ \\
\hline
\end{tabular}

$\mathrm{AB}=$ Anton Berto, $\mathrm{AE}=$ Anthony Erskine, $\mathrm{AG}=$ Tony Gaston, $\mathrm{BL}$ $=$ Bruce Lyon, $\mathrm{CE}=$ Christine Eberl, $\mathrm{CH}=$ Coleen Hyslop, $\mathrm{CJ}=$ Christine James, CK = Clint Kelly, CR = Christoph Rohner, DA = David Andrews, $\mathrm{DC}=$ Don Croll, $\mathrm{DD}=$ Dirk Draulans, $\mathrm{DN}=$ Dave Noble, $\mathrm{EH}=$ Ellen Hayakawa, EM = Elizabeth McLaren, GB = Gwyllim Blackburn, GD = Garry Donaldson, GG = Grant Gilchrist, $\mathrm{GGi}=$ Graeme Gissing, GI = Gabriella Ibarguchi, $\mathrm{HO}=$ Henri Ouellet, IS = Ilya Storm, JG = John Geale, JN = Josiah Nakoolak, $\mathrm{KA}=$ Karel Allard, KB = Kate Bredin, KK = Kaj Kampp, KL = Kara Lefevre, $\mathrm{LD}=$ Leah de Forest, LP = Luc Pelletier, MH = Mark Hipfner, $\mathrm{MK}=$ Maureen Kay, $\mathrm{MP}=$ Marco Passeri, $\mathrm{PP}=$ Paul Prior, $\mathrm{RE}=$ Richard Elliot, $\mathrm{RP}=$ Richard Poulin, $\mathrm{SD}=$ Sandra Dickman, $\mathrm{SJ}=$ Sue Johnson, SP = Sophia Perin, SS = Stephen Smith, SW = Steve Wendt, $\mathrm{TA}=$ Thomas Alogut, $\mathrm{WG}=\mathrm{W} . \mathrm{W} . \mathrm{H}$. Gunn.

1920 to August 1922 and again from August 1923 to August 1924 (when the post was moved to Coral Harbour, Southampton Island), and M.L. Manning during the intervening year. Ford kept many more notes than Manning, and some of his comments concerning wildlife on Coats Island were also quoted by Sutton (1932), who stayed with him at Coral Harbour in 1928-29. For the first year, the log kept at the Coral Harbour post continued to be headed "Coats Island," although the geographical references make it clear that it applied to the Southampton Island area. These misleading headings may be the origin of some errors of mammal distribution shown by Banfield (1974; e.g., ermine were included in fur returns for "Coats Island" in 1924-25, but these figures must refer to the Coral Harbour post).

Other biological work has been carried out at Coats Island in addition to the CWS studies reported here. In 1967, a CWS team captured caribou on the island for transport to Southampton Island, where the indigenous population had been hunted out (F.G. Cooch, pers. comm. 1996). Periodic surveys of caribou on the island were conducted by the Canadian Wildlife Service (Harington, 1965) and the Department of Renewable Resources, Government of the Northwest
Territories (Gates et al., 1986). Intensive studies were carried out in $1982-84$ by J. Adamczewski, which involved visits in every month from March to December, mainly to the south end of the island (Adamczewski et al., 1987, 1988, 1993). F. Bruemmer (pers. comm. 1996) spent two months on the island with a polar bear marking project in 1967. In 1983, R. Decker carried out a general survey of wildlife as part of the Lands Directorate Land Use Mapping project (Lands Directorate, 1984; A.J. Gaston participated in some of the aerial surveys involved). In addition, A.G. Loughrey (1953, 1959, pers. comm. 1992), Mansfield (1976, 1977; Mansfield and St. Aubin, 1991), and Miller (1982) all studied walrus near Cape Pembroke, and Loughrey also banded some murres. Additional studies of walrus at Cape Pembroke and Cape Prefontaine were carried out by the Department of Fisheries and Oceans in 1991. A few other brief visits have been made by biologists travelling by boat from Coral Harbour (C.R. Harington, pers. comm. 1992; Smith, 1966), but none of them seem to have stayed on the island. The above appear to be the sum total of observations on birds and mammals by biologists at Coats Island: there has been no previous publication devoted solely to the birds or mammals of this area.

Few geographical place names are shown on maps of Coats Island. We developed a number of local names during our field work, and these are used throughout the text for convenience (Fig. 2). Observations made within a day's walk of the National Museum of Natural Sciences camp are summarized in the species accounts under the heading "Cairn Cove," while those made by observers based at the Canadian Wildlife Service camp are summarized under "Cape Pembroke."

\section{WEATHER AND SEA ICE}

Weather conditions were recorded daily at 1700 EDT at the Canadian Wildlife Service camp, $100 \mathrm{~m}$ asl. Temperatures during our visits ranged from a minimum of $-10^{\circ} \mathrm{C}$ in May 1990 (our earliest year) to a maximum of $+23^{\circ} \mathrm{C}$ in late July and early August 1991, the warmest year overall (Table 2). Mean maximum temperatures were highest during July, when they were generally between $12^{\circ}$ and $15^{\circ} \mathrm{C}$ (Fig. 3). Minimum temperatures were generally below freezing until about 20 June, reaching maxima of about $5^{\circ} \mathrm{C}$ in late July and early August. A comparison with temperature records maintained at the south end of the island in 1982-84 showed a very similar range during the summers of 1982 and 1983, with maxima reaching $18^{\circ}$ to $20^{\circ} \mathrm{C}$ in July and minima down to $3^{\circ} \mathrm{C}$. However, in 1982 the first temperature below $0^{\circ}$ was not recorded until 13 September, whereas in 1983 temperatures dipped below freezing periodically throughout July and almost daily in August. The spring of 1984 appears to have been exceptionally cold; the temperature did not rise above freezing until 14 June (J. Adamczewski, pers. comm. 1996).

Precipitation was common throughout the summer, with at least a trace on $36 \%$ of days in June, $44 \%$ in July, and $45 \%$ in August. The latest date on which snow fell in spring was 24 June in 1992. A few flurries occurred in late August in 1994. 


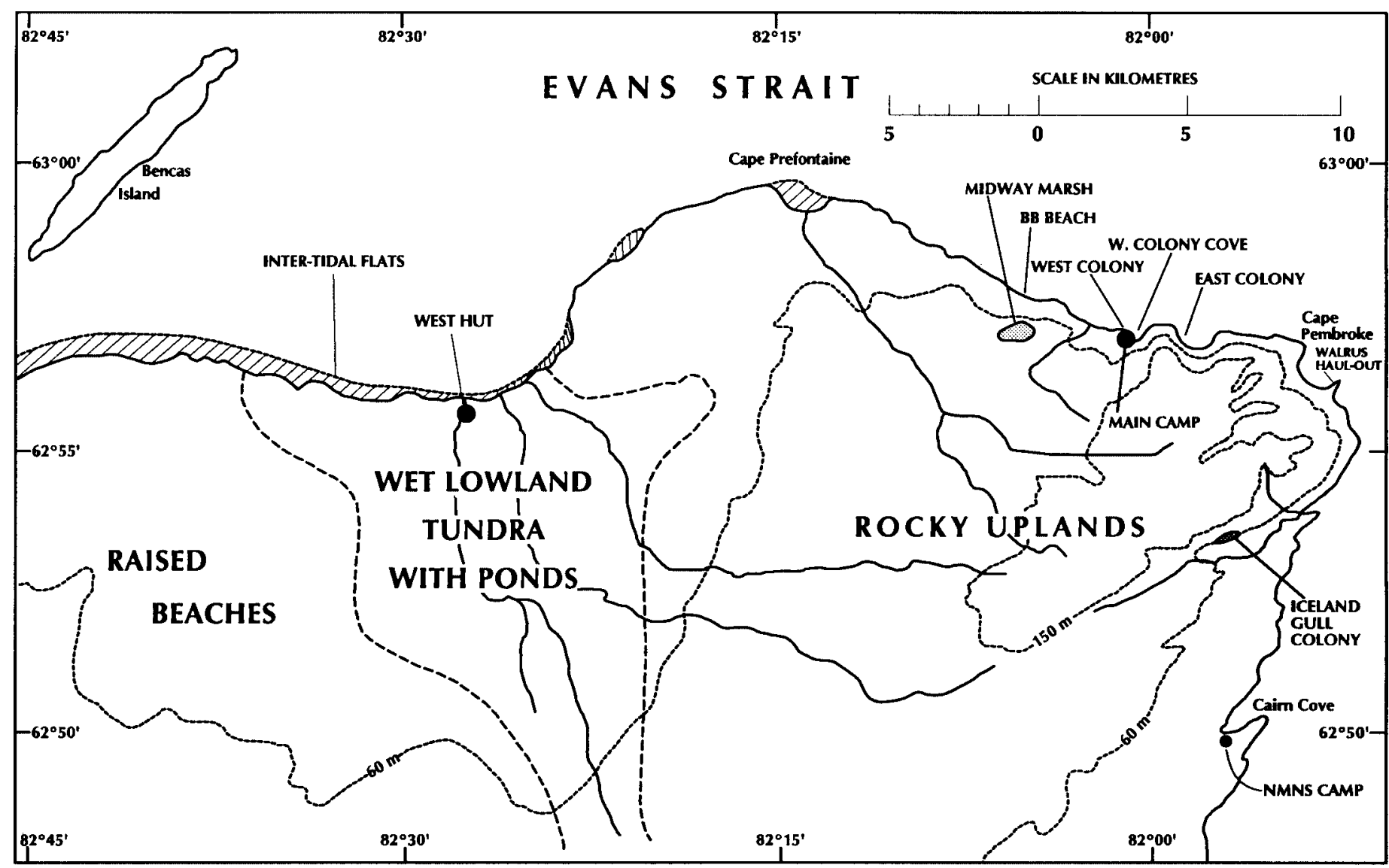

FIG. 2. Map of the north end of Coats Island, showing localities mentioned in the text.

TABLE 2. Summary of weather at Coats Island, main camp, recorded at 1700 EDT daily: percentage of days with winds greater than $20 \mathrm{~km} \mathrm{~h}^{-1}$ (> 20) and greater than $40 \mathrm{~km} \mathrm{~h}^{-1}$ (> 40); percentage of days with at least a trace of rain, and mean maximum and minimum temperatures $\left({ }^{\circ} \mathrm{C}\right)$.

\begin{tabular}{|c|c|c|c|c|c|c|c|c|c|c|c|c|c|c|c|}
\hline \multirow[t]{2}{*}{ Year } & \multicolumn{5}{|c|}{ June } & \multicolumn{5}{|c|}{ July } & \multicolumn{5}{|c|}{ August } \\
\hline & $\begin{array}{l}\text { Wind } \\
>20\end{array}$ & $\begin{array}{l}\text { Wind } \\
>40\end{array}$ & $\begin{array}{l}\text { Rain } \\
\text { Days }\end{array}$ & $\begin{array}{c}\text { Max } \\
\text { Temp }\end{array}$ & $\begin{array}{c}\text { Min } \\
\text { Temp }\end{array}$ & $\begin{array}{l}\text { Wind } \\
>20\end{array}$ & $\begin{array}{l}\text { Wind } \\
>40\end{array}$ & $\begin{array}{l}\text { Rain } \\
\text { Days }\end{array}$ & $\begin{array}{c}\text { Max } \\
\text { Temp }\end{array}$ & $\begin{array}{c}\text { Min } \\
\text { Temp }\end{array}$ & $\begin{array}{c}\text { Wind } \\
>20\end{array}$ & $\begin{array}{l}\text { Wind } \\
>40\end{array}$ & $\begin{array}{l}\text { Rain } \\
\text { Days }\end{array}$ & $\begin{array}{c}\text { Max } \\
\text { Temp }\end{array}$ & $\begin{array}{c}\text { Min } \\
\text { Temp }\end{array}$ \\
\hline 1985 & & & & & & 0 & 0 & $50 \%$ & 15.0 & 5.2 & $9 \%$ & 0 & $63 \%$ & 9.9 & 3.3 \\
\hline 1986 & & & & & & $12 \%$ & 0 & $25 \%$ & 15.1 & 4.9 & $44 \%$ & $33 \%$ & $55 \%$ & 9.7 & 4.8 \\
\hline 1987 & & & & & & $50 \%$ & $12 \%$ & $50 \%$ & 13.1 & 3.4 & $58 \%$ & $24 \%$ & $47 \%$ & 12.4 & 3.7 \\
\hline 1988 & $38 \%$ & $19 \%$ & $29 \%$ & 9.4 & 0.1 & $29 \%$ & $10 \%$ & $39 \%$ & 14.2 & 4.3 & $69 \%$ & $25 \%$ & $50 \%$ & 10.8 & 5.1 \\
\hline 1989 & & & & & & $50 \%$ & 0 & $75 \%$ & 14.7 & 7.7 & $53 \%$ & $11 \%$ & $58 \%$ & 9.9 & 3.8 \\
\hline 1990 & $40 \%$ & $17 \%$ & $30 \%$ & 5.4 & -1.2 & $52 \%$ & $29 \%$ & $65 \%$ & 10.9 & 4.0 & $70 \%$ & $35 \%$ & $52 \%$ & 8.7 & 3.4 \\
\hline 1991 & $42 \%$ & $12 \%$ & $35 \%$ & 10.9 & 1.5 & $39 \%$ & $13 \%$ & $32 \%$ & 14.2 & 3.9 & $48 \%$ & $22 \%$ & $41 \%$ & 13.7 & 5.2 \\
\hline 1992 & $45 \%$ & $9 \%$ & $59 \%$ & 3.7 & -0.9 & $29 \%$ & 0 & $32 \%$ & 10.3 & 1.9 & $48 \%$ & $30 \%$ & $9 \%$ & 12.0 & 3.9 \\
\hline 1993 & & & & & & $27 \%$ & $7 \%$ & $20 \%$ & 14.7 & - & $50 \%$ & $25 \%$ & $50 \%$ & 11.7 & - \\
\hline 1994 & $52 \%$ & $24 \%$ & $52 \%$ & 9.3 & 2.1 & $35 \%$ & $6 \%$ & $37 \%$ & 14.7 & 5.1 & $33 \%$ & $14 \%$ & $57 \%$ & 10.0 & 4.3 \\
\hline 1995 & $50 \%$ & $25 \%$ & $18 \%$ & 10.0 & 0.0 & $55 \%$ & $16 \%$ & $68 \%$ & 10.5 & 3.0 & $35 \%$ & $10 \%$ & $35 \%$ & 11.9 & 5.0 \\
\hline 1996 & $60 \%$ & $17 \%$ & $47 \%$ & 6.1 & -0.2 & $43 \%$ & $17 \%$ & $20 \%$ & 18.1 & 5.7 & $62 \%$ & $19 \%$ & $62 \%$ & 9.9 & 4.1 \\
\hline
\end{tabular}

Otherwise, precipitation in summer fell as rain. It was sometimes very heavy: $115 \mathrm{~mm}$ fell in three days during 7-9 August 1986, including $64 \mathrm{~mm}$ on 8 August alone. Thunderstorms were occasional in July and early August. The year with most frequent rain was 1990, when precipitation occurred on $49 \%$ of days, and the driest year was 1992, which had precipitation on only $33 \%$ of days.

High winds are a notable feature of Coats Island. In 1990, the windiest year, three storms with winds over $100 \mathrm{~km} \mathrm{~h}^{-1}$ were recorded, and winds over $40 \mathrm{~km} \mathrm{~h}^{-1}$ occurred on $26 \%$ of days. From 25 July to 1 August, daily wind speeds at 1700 were between 30 and $90 \mathrm{~km} \mathrm{~h}^{-1}$ and between 14 and 22 August, every day had winds over $60 \mathrm{~km} \mathrm{~h}^{-1}$, and one day the wind speed exceeded $100 \mathrm{~km} \mathrm{~h}^{-1}$. In November 1982, J. Adamczewski (pers. comm., 1996) estimated a wind speed of $160 \mathrm{~km} / \mathrm{h}$ at the south end of the island. Wind speeds tend to be somewhat lower in July than in early June and late August (Fig. 4). Strong winds come mainly from the southwest and 


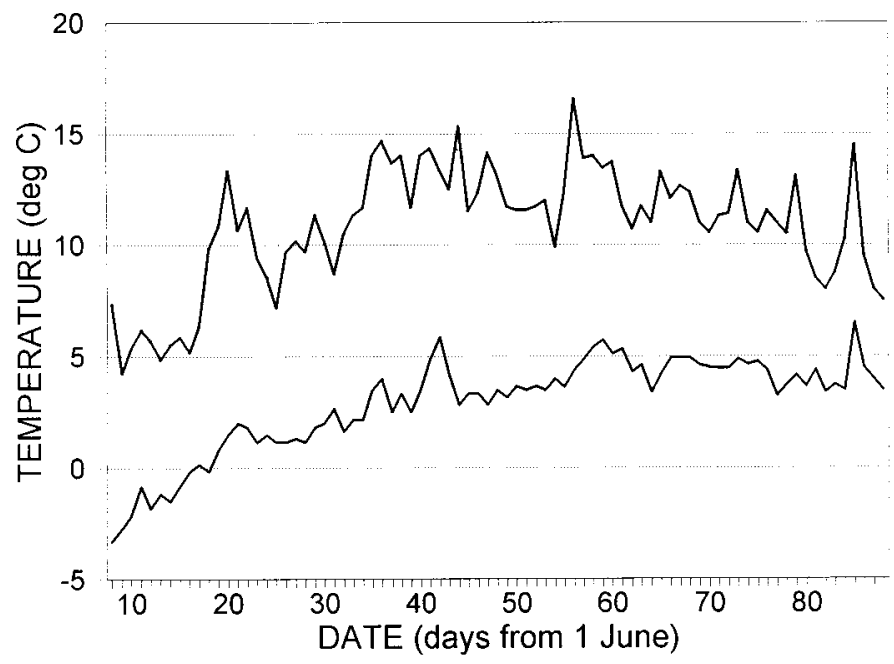

FIG. 3. Maximum and minimum temperatures at camp, near Cape Pembroke, averaged over all years.

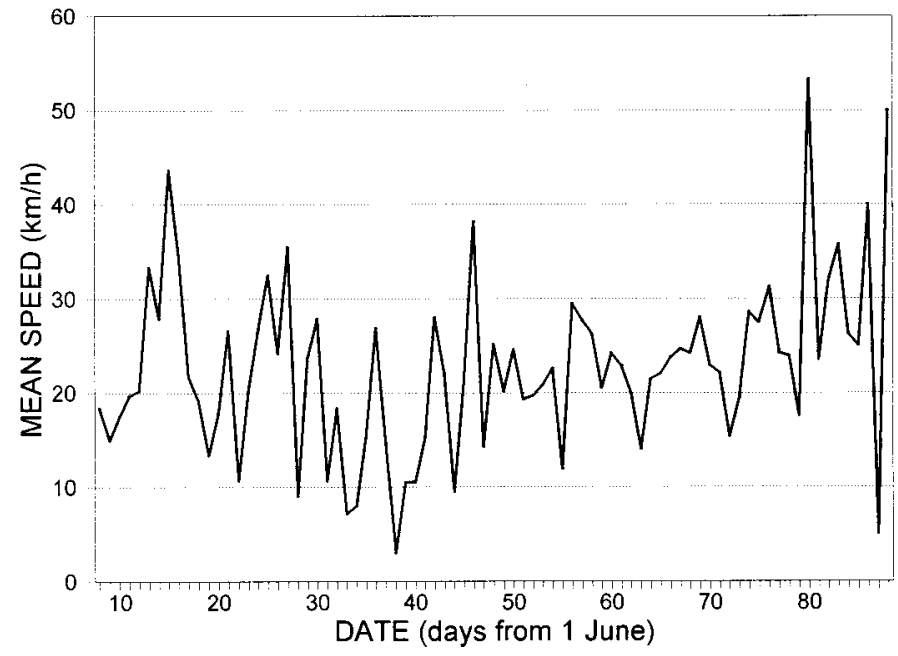

FIG. 4. Mean wind speeds at camp at $1700 \mathrm{hrs,} \mathrm{averaged} \mathrm{over} \mathrm{all} \mathrm{years.}$

west, with $52 \%$ of winds over $40 \mathrm{~km} \mathrm{~h}^{-1}$ coming from these two directions. This is in contrast to the situation at Coral Harbour, where most strong winds come from the north (Maxwell, 1985), a situation that also pertains at Coats Island in winter (Adamczewski, 1996).

Snow generally persists on Coats Island from late October to mid-June (Adamczewski et al., 1988). During 1990-95, cover was variable in June, with extensive snow persisting through mid-June in 1990 and to late June in 1992 and 1996; in other years, there was little snow lying by 15 June except on north-facing slopes. Sea-ice cover was likewise very variable. The dates after which ice did not cover more than $50 \%$ of the sea area visible from camp ranged from 20 June in 1995 to 3 August in 1992. The date after which no further sea ice was visible ranged from 2 July in 1995 to 5 August in 1992 (Table 3). Although landfast ice always develops for several kilometres offshore from the camp location, ice usually remains mobile in Evans Strait throughout the winter, and major shore leads are present on the east coast of Coats
TABLE 3. Dates of sea-ice clearance from the northeast tip of Coats Island in years when camp was operated from June.

\begin{tabular}{lccc}
\hline \hline Year & $\begin{array}{c}\text { Date after which } \\
\text { ice cover }<50 \%\end{array}$ & $\begin{array}{l}\text { Date after which } \\
\text { no ice seen }\end{array}$ & $\begin{array}{l}\text { Date fast ice cleared } \\
\text { from west colony cove }\end{array}$ \\
\hline 1988 & 28 June & 26 July & 4 July \\
1990 & 13 July & 25 July & 7 July \\
1991 & 16 July & 21 July & 6 July \\
1992 & 3 August & 5 August & 16 July \\
1994 & 29 June & 8 July & 22 June \\
1995 & 20 June & 2 July & 17 June \\
1996 & 13 July & 21 July & 22 June \\
\hline
\end{tabular}

Island and the south coast of Southampton Island (Markham, 1985). These circumstances combine to prevent travel between Southampton and Coats Islands during the winter.

A striking annual phenomenon that may be a good indication of the timing of the terrestrial season is the first emergence of significant numbers of mosquitos. This occurred between 5 and 13 July in all years except 1992, when there was no large emergence until 31 July. First reports of large numbers of mosquitos in the Hudson's Bay journals were on 28 June and 15 and 21 July. Overall, 1992 stood out as a very late year, in terms of both sea-ice cover and events in the terrestrial environment (flowering times, mosquitos). Maximum temperatures in June and July were lower that year than in any other.

\section{ECOLOGY}

A plant list for the island has been published by Gillett (1976), who remarked on the generally eastern affinities of the flora. The land-use survey of Coats Island conducted in 1983 (Lands Directorate, 1984) classified the island as falling within the Boothia-Foxe Lowlands Ecoregion, characterized by low relief, raised beaches, and silty marine deposits overlying limestone bedrock, with numerous small lakes and very low herbaceous vegetation or prostrate shrubs. The island was divided into four ecodistricts, of which the CWS teams visited only two: a) low-lying coastal wetlands with numerous pools of 1-100 ha, dominated by sedges Eriophorum spp., Carex spp. and low-growing heaths Cassiope tetragona, Empetrum nigrum, interspersed with beach ridges supporting Dryas tundra; and b) rocky uplands, covered in places with raised beach deposits and moraines and supporting a low heath of Cassiope tetragona, Vaccinium uliginosum and decumbent Salix spp., as well as abundant Dryas integrifolia and Saxifraga oppositifolia (Figs. 2, 5-7). The main camp beside the thick-billed murre colonies was situated in the centre of the rocky uplands (Cape Pembroke area). Consequently, most of the observations of terrestrial biota were made in this ecodistrict. The west hut was in an area of low-lying coastal wetlands and the only significant information on the fauna of this ecodistrict was made during the three expeditions there ("West Hut" area). Observations are summarized by ecodistrict. 


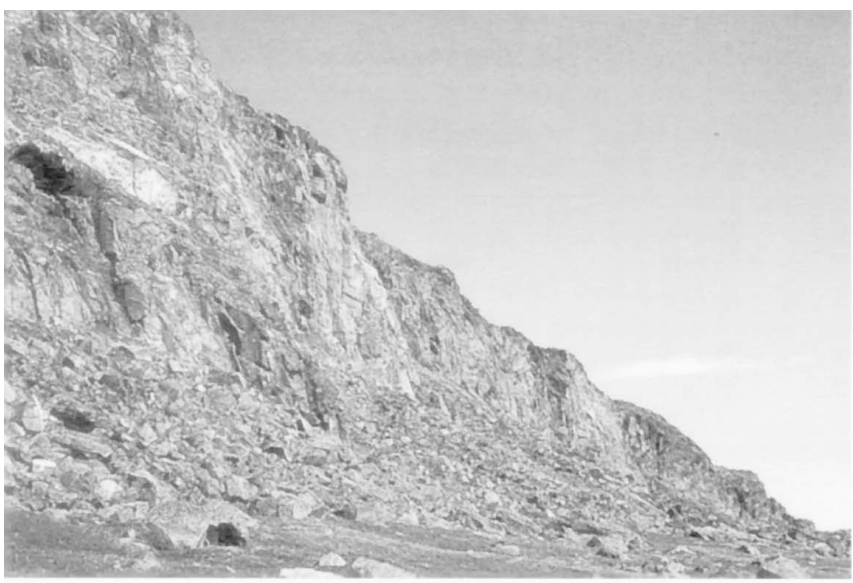

FIG. 5. The main gull colony, north of Cairn Cove, July 1975.

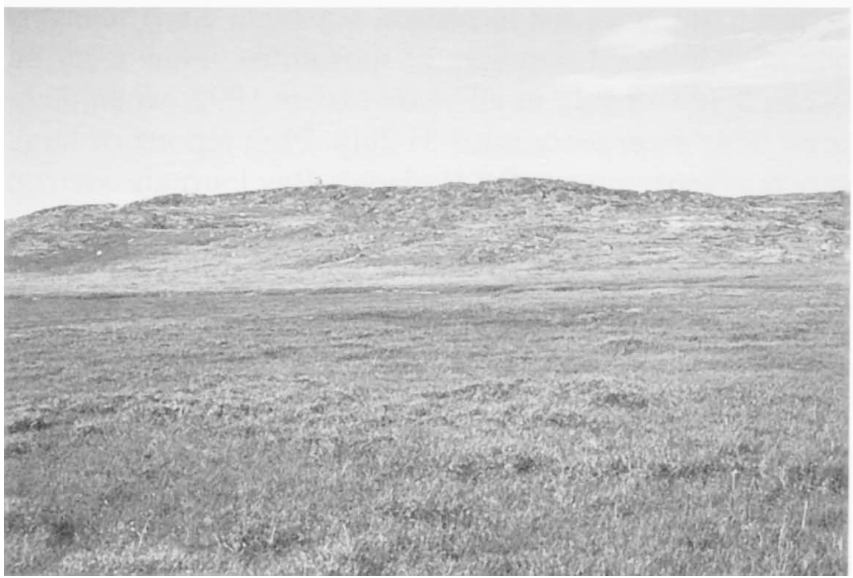

FIG. 6. Wet lowland tundra inland of Cairn Cove, July 1975.

\section{MAMMAL AND BIRD OBSERVATIONS}

\section{Mammals}

The names and order follow Banfield (1974).

Arctic Hare Lepus arcticus: Although Banfield showed this species as occurring on Coats Island, there is no evidence from either our observations, those of Adamczewski, Hudson's Bay Company (HBC) records, or the testimony of local people that hares have ever occurred on the island.

Lemmings Lemmus and Dicrostonyx species: Lemmus sibiricus and Dicrostonyx torquatus both occur on Southampton Island (Sutton and Hamilton, 1932), but despite keeping a sharp lookout for droppings and runways, we saw no evidence that lemmings occurred on Coats Island during our visits, nor did J. Adamczewski (pers. comm. 1996). Bruemmer (1969) reported no sign of lemmings in his twomonth visit, and their presence in the past is doubtful.

Beluga Delphinapterus leucas: C. PEMBROKE: Groups of up to 30 were seen occasionally between 20 June and 16 August in most years. Large pods were sometimes present in late June-early July: up to 300 were seen from camp between 20 June and 10 July 1994, 200+ passed on 27 June 1995, and

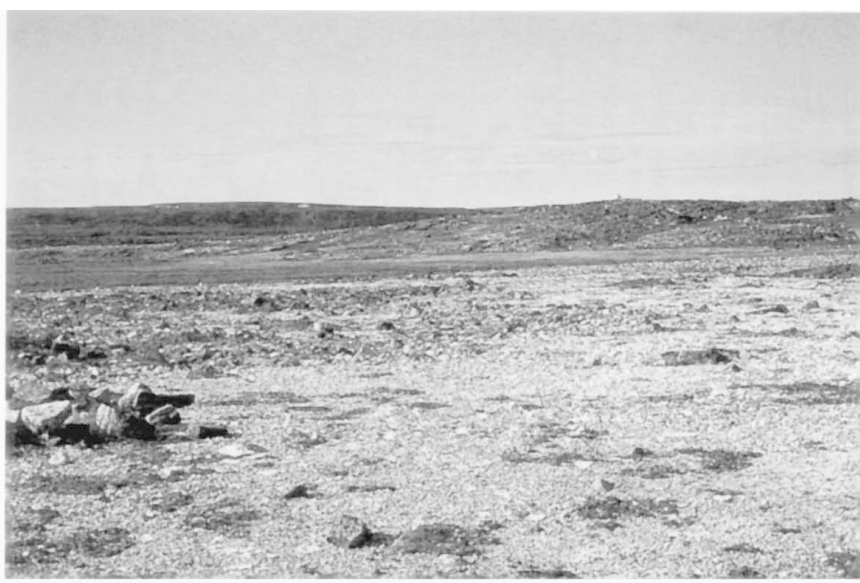

FIG. 7. Raised beach ridges inland of Cairn Cove, July 1975.

200 were present on 8 July 1996. In all three years, the large groups moved slowly, within $400 \mathrm{~m}$ of shore, and dived repeatedly, suggesting that they were feeding intensively. HBC: Two belugas were killed in February, supporting the idea that some overwinter in the area (Richard, 1993). Large numbers were reported in June and early July, and on 14 September 1924, when the cove at the post was reported "white with white whales."

Narwhal Monodon monoceros: A skull with a complete tusk, from an animal not long dead, was found by J. Nakoolak on Bencas Island on 31 July 1995.

Killer Whale Orcinus orca: C. PEMBROKE: Three were seen heading east on 16 July 1990.

Bowhead Whale Balaena mysticetus: C. PEMBROKE: One was seen in the west colony cove on 30 July 1991. In 1995, one was seen on 30 August, moving slowly west about $1 \mathrm{~km}$ offshore, taking dives of 8, 10, and 24 min. HBC: Sightings of "large whales" (sometimes "Greenland whales") are presumed to refer to bowheads. They were seen in April (once) and on many occasions during June-October, but not more than two together. A small female, about $9 \mathrm{~m}$ long, was killed and brought ashore on 18 July 1921, and a much larger whale, more than $20 \mathrm{~m}$ long, was killed about $60 \mathrm{~km}$ off Cape Pembroke on 10 August 1922, but had to be cast adrift in a storm and was lost. One other whale was wounded on 2 July 1922. These records seem to have been overlooked by Reeves et al. (1983) in their summary of bowhead observations in the eastern Arctic.

Wolf Canis lupus: HBC: A report of wolf tracks seen in February 1921 is the only evidence of wolves on the island.

Arctic Fox Alopex lagopus: CAIRN COVE: One active den with kits was observed on 23 July 1975. C. PEMBROKE: At least four adults (individually identifiable by their pelage) were seen around the thick-billed murre colonies in every year. A den at the foot of the hill below camp was occupied in all years except 1988 and 1993. One in the centre of the east murre colony was occupied in at least four years. When landfast ice was present in the west colony cove, foxes regularly hunted murres that became stranded on the ice after landing on meltwater puddles too small for take-off. Many of 
the carcasses were taken to kits in the adjacent den; some were scavenged by glaucous gulls. Later in the season, the adults foraged on the top edges of the murre colony cliff, taking eggs, chicks, and occasionally adults. Many eggs were cached in moss peat near the camp. Up to five kits were seen playing outside the den near camp after mid-July and visited camp from about 10 August in several years. WEST HUT: Singles were seen in 1994 and 1995. J. Adamczewski (pers. comm. 1996) reported that foxes were common at the south end of the island in 1982-84: in March-April 1981, 31 were caught in that area by a single trapper. HBC: Even in the first year of operation, foxes were referred to as very scarce. Although complete fur returns are not available, the post seems to have traded less than 100 annually. This compares with 555 at Coral Harbour in the first year of operation by the same person (Ford).

Red Fox Vulpes vulpes: CAIRN COVE: One was seen $2 \mathrm{~km}$ inland on 25 July 1975 . Bruemmer (1969) also saw one on the island. However, there was no evidence of the species from CWS records, or those of the HBC post. Banfield (1974) shows it occurring on Coats Island, but the species may be an intermittent arrival across the sea ice.

Polar Bear Ursus maritimus: C. PEMBROKE: Bears, or their tracks, were seen in every year, with bears recorded on a maximum of 16 days in 1987. First sightings on land in the full seasons ranged from 19 June in 1991 and 28 June in 1995, years of very early ice breakup, to 12 August in 1992, a very late ice year. Up to 1988, a total of 28 were seen, all solitary. Subsequently, females with one or two cubs were seen ashore in 1989 (2 families), 1993 (1 family), 1994 (1 family) and 1995 ( 2 families), along with a further 28 sightings of solitary bears. Three different individuals were seen during 8-10 September 1995, which suggests that bears become more common, or more mobile, in the fall. BENCAS ISLAND: Three bears were present on 31 July 1995 . WALRUS ISLAND: Five were sighted on 22 July 1993, including a female with two cubs. HBC: Records indicate that most bears were killed on the island in August-October. Presumably most were in their dens after October. Several records of females with very young cubs in February show that some maternity denning occurred on the island. Exact fur returns are not available, but post records suggest that about 70 bears were killed annually.

Ermine Mustela erminea and Wolverine Gulo gulo: Banfield (1974) showed ermine and wolverine as occurring on Coats Island, but they were not recorded by us or by the managers of the HBC post.

Lynx Lynx lynx: HBC: Tracks were reported by Inuit in February 1922. This sighting may be the basis for the extralimital record shown by Banfield (1974) on Coats Island. The species has not been reported on Southampton Island; we saw no sign of them.

Walrus Odobenus rosmarus: There are several regular and numerous irregular walrus haul-outs around Coats Island (Mansfield and St-Aubin, 1991). C. PEMBROKE: A regular haul-out on a rocky promontory just south of Cape Pembroke was visited by team members nearly every year. Counts were as follows: 1981, 500-600 hauled out and c. 1000 in area on 15 August; 1986, none on 5 August; 1988, 50 on 29 July; 1991 , none on 30 June, $400-500$ on 25 July (150 on sand beach to west, the rest on the rocky point), c. 30 on 13 August; 1992, none on 27 July, c. 600 on 7 August, several hundred on 14 August; 1993, 25 on 7 August; 1994, none on 21 June, 30 on 7 July, 60 on 16 July, 11 on 6 August; 1995,3 on 18 July, none on 19 August, 75 on 24 August, none on 28 August and 5 September; 1996, one on 19 July, 12 on 17 August. Signs of predation by polar bears at this haul-out were seen in four years. Another regular haul-out visited several times was on a small island called "Kahlooktuk," near Cape Prefontaine, where c. 150 were present on 5 August 1992, and c. 500 on 31 July 1995. From camp, walrus were generally first seen soon after ice breakup, the earliest record being 24 June 1994. They sometimes fed in the west colony cove, with maxima of 100 recorded on 6-14 August 1992 and 125 on 8 July 1994. Walruses occasionally attempted to prey on murres in the water, sometimes successfully (Donaldson et al., 1995). HBC: The journals reported walruses killed in November, February, March, and April, as well as in summer, showing that some were present around the island throughout the year.

Bearded Seal Erignathus barbatus: C. PEMBROKE: Singles were seen hauled out on shorefast ice in 1988, 1992, 1994, and 1995. HBC: "Square-flippers" were killed periodically throughout the winter.

Harbour Seal Phoca vitulina: C. PEMBROKE: One was seen in the west colony cove on several occasions in August 1995.

Ringed Seal Phoca hispida: C. PEMBROKE: This species was commonly seen hauled out on landfast ice in the early part of the season. The maximum count from camp was 20 , on 19 June 1994. Ringed seals were not seen in years when the ice had disappeared before our arrival.

Harp Seal Phoca groenlandica: C. PEMBROKE: Harp seals were seen only in 1995 , when herds of up to 20 were seen on three dates during 23-30 August. Several herds were seen at sea between Coats and Southampton Islands on 24 July 1993.

Caribou Rangifer tarandus: The population of barrenground caribou (R. tarandus groenlandicus) on Coats Island has fluctuated considerably since 1961, with estimates ranging from 900 to 6000 (Gates et al., 1986). The higher estimate included 4400 carcasses present in 1975 after a die-off during the previous winter. Between 7 June and 2 July 1967, 38 adult caribou (12 males, 26 females) and 10 calves captured on Coats Island were released alive on Southampton Island (Manning, 1967). Details of factors affecting population size and condition on Coats Island are given by Adamczewski et al. (1987, 1988, 1993). C. PEMBROKE: Caribou were not recorded until 1987, after which small numbers, usually not more than four together, were seen annually. In 1992, the carcasses of three adult caribou were found on sea ice at the foot of the west colony cliffs. They had apparently fallen to their deaths in the winter and provided an important source of food for glaucous gulls until the ice melted. WEST HUT: One to three animals were seen in all years. HBC: Records 
indicate that caribou were common on the island and regularly hunted by people associated with the post. Most were shot on trips of several days away from the post, suggesting that caribou were not common around the post at any time.

\section{Birds}

Names and sequence follow the American Ornithologists' Union Check-list of North American Birds, 6th edition (1983) and supplements (Monroe et al., 1985, 1987, 1989, 1991, 1993, 1995). Records are summarized by year in Table 4 .

Red-throated Loon Gavia stellata: CAIRN COVE: This is a very common breeder on small ponds inland from the coast; up to 50 have been seen in a day, including three family groups on 21 July 1975. C. PEMBROKE: Up to six were seen every year on the sea close inshore. Breeding was recorded on small ponds up to $2 \mathrm{~km}$ inland in 1986, 1988, and 1994. WEST HUT: The species is a common breeder, nesting on small islands in lakes smaller than 3 ha. In 1993, eight broods of chicks less than 20 days old were seen, and one nest contained eggs. In 1994 and 1995, three nests were located, all being incubated. Birds were seen feeding close inshore in shallow water, often in the surf zone. BENCAS ISLAND: Two were present on 31 July 1995.

Pacific Loon Gavia pacifica: CAIRN COVE: Up to 15 adults were seen daily, including two nests, during 21-27 July 1975. C. PEMBROKE: Small numbers $(1-3)$ were seen annually on the sea from early July. WEST HUT: Pacific loons were common on large ponds and lakes larger than 2 ha up to $2 \mathrm{~km}$ inland. In 1993, one bird was incubating on a small island in a 3 ha lake, and one pair with 1-2 wk chicks was seen on a 5 ha lake. In 1994, 11 pairs were located, including 5 incubating, all on islands in lakes larger than 2 ha. One incubating pair was seen in 1995. BENCAS ISLAND: At least 10 were seen, including one bird incubating on a nest.

Common Loon Gavia immer: CAIRN COVE: There are two records from 21-27 July 1975.

Northern Fulmar Fulmarus glacialis: Single pale-morph birds visited the west murre colony on 11 June 1991, 3 July 1995, and 5 August 1996. Small numbers, all pale morph, were seen on boat trips to and from Coral Harbour in late July 1992, 1993, and 1994. On 27 July 1993 eight were seen between Coats and Mansel Islands.

Great Blue Heron Ardea herodias: One was present at the west murre colony on 11 August 1991.

TundraSwan Cygnus columbianus: CAIRNCOVE: Three family groups with two, three, and four young were seen during 21-23 July 1975. C. PEMBROKE: One or two were spotted flying over on eight dates in four years. WEST HUT: Up to three breeding pairs were seen in all years. In 1993, a pair had three cygnets c. 15 days old; in 1994, two pairs each had two cygnets less than 10 days old; and in 1995, two pairs were seen, but no young. The species bred commonly near the south end of the island in 1982-84 (J. Adamczewski, pers. comm., 1996). BENCAS ISLAND: Four were present on the sea on 31 July 1995.
Greater White-fronted Goose Anser albifrons: C. PEMBROKE: One was seen on the camp beach on 10 June 1990, and two with a flock of Canada geese on 31 May 1996.

Snow Goose Chen caerulescens: CAIRN COVE: Up to four were seen during 21-27 July 1975. C. PEMBROKE: Spring passage lasted to mid-July, with peak numbers flying north from 1-7 June 1990. On fall migration, snow geese were seen annually after about 8 August in flocks arriving from the north and northeast. Peak arrivals occurred on 21 August in 1994 and 23 August in 1995 and 1996, when thousands were seen flying in from the sea. In 1995, many tens of thousands were present around lakes and on sedge meadows to the south of camp on 28 August. Numbers were noticeably lower by 4 September. Flocks of apparently orphaned juveniles remained about camp during 1-7 September 1995. In late August 1993-95 at least 50 juveniles were found dead along the shoreline, apparently having arrived exhausted; these were actively scavenged by gulls, foxes (who may have killed some), and bears. Two flocks greater than 100, seen on 4 September 1995, comprised all whitemorph geese and looked larger than earlier arrivals; these could have been C. c. atlantica. WEST HUT: In 1993 and 1994, moulting flocks numbering several hundred were present (50:50 blue and white morph), but only five individuals were seen in 1995. HBC: Strangely, snow geese are not referred to at all, nor are there any references to geese being shot, although other species killed (murres, ptarmigan) are frequently mentioned. However, Sutton (1932) quoted Ford as saying that snow geese had been numerous in fall, but probably did not breed on the island (and apparently they still do not).

Brant Branta bernicla: C. PEMBROKE: A single bird was seen on 26 August 1991, and a family party was present on the beach on 28 and 29 August. In 1992, a single bird was seen on 22 June, two on 8 July and nine on 9 July. A flock of 40 landed on the sea on 7 September 1995. WEST HUT: Five birds were present on coastal marshes in 1994 and six in 1995. AERIAL SURVEYS: Brant were common on southern and western areas in 1983 (Gaston et al., 1986). HBC: Brant were reported "passing in large flocks" on 4 September 1920.

Canada Goose Branta canadensis: CAIRN COVE: Four family groups with two, three, three, and five young were seen during 21-25 July 1975. C. PEMBROKE: Canada geese were seen in all years, with spring passage or moult migration (usually flocks of less than 25) apparently lasting until mid-July and fall passage (flocks of less than 100) of small geese (presumably B. c. hutchinsii, which breeds on Southampton Island) occurring after about 10 August. The first sighting was on 28 May in 1990. Geese were present on 26 May in 1996. In some years, flocks of moulting Canada Geese of one of the large, long-necked southern races occurred near upland lakes inland of camp. The only record of breeding near camp was a pair that nested on the west murre colony cliff in 1992. WEST HUT: A pair was seen with three small goslings in 1993; four nests with eggs and three broods of small goslings $(2,2$, and 3) were seen in 1994; and two nests with eggs were seen in 1995. AERIAL SURVEYS: 
TABLE 4. Summary of bird observations on northern Coats Island, by year: $*=$ observed, B = evidence of breeding.

\begin{tabular}{|c|c|c|c|c|c|c|c|c|c|c|c|c|c|c|c|}
\hline & 1975 & 1981 & 1984 & 1985 & 1986 & 1987 & 1988 & 1989 & 1990 & 1991 & 1992 & 1993 & 1994 & 1995 & 1996 \\
\hline Red-throated Loon & B & $*$ & $*$ & $*$ & $*$ & $*$ & $*$ & $*$ & $*$ & $*$ & $*$ & $*$ & B & B & $*$ \\
\hline Pacific Loon & B & * & $*$ & * & * & * & $*$ & $*$ & * & * & * & & $\mathrm{B}$ & B & * \\
\hline Common Loon & $*$ & & & & & & & & & & & & & & \\
\hline Northern Fulmar & & & & & & & & & & * & & & & $*$ & $*$ \\
\hline Great Blue Heron & & & & & & & & & & * & & & & & \\
\hline Tundra Swan & B & & & & & & & & $*$ & $*$ & $*$ & $*$ & B & B & $*$ \\
\hline Greater White-fronted Goose & & & & & & & & & * & & & & & & $*$ \\
\hline Snow Goose & $*$ & & $*$ & $*$ & & & $*$ & $*$ & * & * & $*$ & $*$ & $*$ & $*$ & $*$ \\
\hline Brant & & & & & & & & & & * & $*$ & & & $*$ & \\
\hline Canada Goose & B & $*$ & $*$ & $*$ & $*$ & $*$ & $*$ & $*$ & $*$ & $*$ & $*$ & $*$ & $\mathrm{~B}$ & B & $*$ \\
\hline Green-winged Teal & & & & & & & & & & & & & & $*$ & \\
\hline Black Duck & & & $*$ & & & & & & & & & & & & \\
\hline Northern Pintail & B & & & & & & & & & & & & $*$ & B & B \\
\hline Common Eider & B & & $*$ & $*$ & & & $*$ & & $*$ & $*$ & B & $*$ & $*$ & $*$ & $\mathrm{~B}$ \\
\hline King Eider & B & B & B & $*$ & $*$ & $*$ & & B & * & B & $*$ & $*$ & B & B & B \\
\hline Oldsquaw & B & & & B & B & & B & $*$ & * & B & $*$ & B & B & B & B \\
\hline Black Scoter & & & & * & & & & & & & & & & & \\
\hline White-winged Scoter & & $*$ & & & & & & & & & & & & & \\
\hline Red-breasted Merganser & $*$ & & & & & & & $*$ & & $*$ & $*$ & & $*$ & $*$ & \\
\hline Rough-legged Hawk & & & & & & & & & & & & & & & $*$ \\
\hline Peregrine Falcon & B & B & B & $\mathrm{B}$ & B & B & B & B & $\mathrm{B}$ & B & B & B & $\mathrm{B}$ & B & $\mathrm{B}$ \\
\hline Gyrfalcon & & & & & & & & & & & $*$ & & & $*$ & \\
\hline Willow Ptarmigan & B & & & & & & & & & & & & & & \\
\hline Rock Ptarmigan & $*$ & $\mathrm{~B}$ & & & B & & & & $\mathrm{B}$ & B & $*$ & B & $*$ & & \\
\hline Sandhill Crane & & & & & & & & & & * & & & $*$ & $*$ & \\
\hline Black-bellied Plover & $*$ & & & & & & & & * & * & $*$ & & $*$ & $*$ & \\
\hline American Golden-Plover & $*$ & & & & $*$ & & & & & $*$ & $*$ & & $*$ & $*$ & \\
\hline Semipalmated Plover & B & $*$ & & $\mathrm{~B}$ & $*$ & & B & & $*$ & B & B & B & $*$ & $*$ & $*$ \\
\hline Greater Yellowlegs & & & & & & & & & & & $*$ & & & & \\
\hline Whimbrel & & & & & & & & & & & & & * & * & * \\
\hline Ruddy Turnstone & B & & & & & & & & $*$ & $*$ & $*$ & $*$ & B & $*$ & \\
\hline Red Knot & $*$ & & & & & & & & & & & & & & \\
\hline Sanderling & $*$ & & & & & & & & & & & & & & \\
\hline Semipalmated Sandpiper & B & & & & & & & & $*$ & & & & B & & $*$ \\
\hline White-rumped Sandpiper & $*$ & * & & & B & & $*$ & & $*$ & & $*$ & B & * & * & \\
\hline Baird's Sandpiper & B & * & & * & $\mathrm{B}$ ? & & & & * & * & $*$ & & & & \\
\hline Pectoral Sandpiper & $*$ & & & & & & & & * & & $*$ & & B & * & \\
\hline Purple Sandpiper & B & $*$ & & & B & & & & B & B & B & & B & * & \\
\hline Dunlin & B & & & & & & & & $*$ & & & $*$ & & $*$ & \\
\hline Stilt Sandpiper & & & & & & & & & * & & & & & & \\
\hline Common Snipe & & & & & & & & & * & & & & & & \\
\hline Red Phalarope & $*$ & & & & & & & & & * & & & B & B & \\
\hline Red-necked Phalarope & * & & & & & & & & & * & & & & & \\
\hline Pomarine Jaeger & $*$ & & & & & & & & & & * & & & & \\
\hline Parasitic Jaeger & $*$ & * & $*$ & & $*$ & & $*$ & $*$ & $*$ & $*$ & $*$ & $*$ & $*$ & * & \\
\hline Long-tailed Jaeger & $*$ & & & & & & & & & $*$ & $*$ & & & & \\
\hline Bonaparte's Gull & & & & & & & & & $*$ & & & & & & \\
\hline Ring-billed Gull & & $*$ & & & & & & & & & & & & & \\
\hline Herring Gull & B & $*$ & & $*$ & $*$ & $*$ & $*$ & $*$ & $*$ & $*$ & $*$ & * & $\mathrm{B}$ & B & * \\
\hline Lesser Black-backed Gull & & & & & & & & & & $*$ & & & & & \\
\hline Great Black-backed Gull & $*$ & & & & & & & & & & $*$ & & $*$ & $*$ & $*$ \\
\hline Iceland Gull & & * & $*$ & B & $*$ & * & $*$ & B & B & * & $*$ & B & B & B & B \\
\hline Glaucous Gull & B & B & B & B & B & B & B & B & B & B & B & B & B & B & B \\
\hline Sabine's Gull & & & & & & & & & & & $*$ & & $\mathrm{~B}$ & B & \\
\hline Arctic Tern & B & & & & & & & & & & & B & B & B & \\
\hline Common Murre & & & & & & & & & $*$ & & & & & & $*$ \\
\hline Thick-billed Murre & B & B & B & B & B & B & B & B & B & B & B & B & B & B & B \\
\hline Black Guillemot & $*$ & * & * & $*$ & * & * & $*$ & $*$ & $*$ & * & $*$ & $*$ & $*$ & B & $\mathrm{B}$ \\
\hline Atlantic Puffin & & & & & & & & & & & & & & & $*$ \\
\hline Snowy Owl & & & & & & & & & $*$ & & $*$ & & & $*$ & \\
\hline Short-eared Owl & & & & & & & & & & & & & & & * \\
\hline Horned Lark & $*$ & & & $\mathrm{~B}$ & B & & $*$ & & $*$ & $*$ & $*$ & $*$ & $*$ & B & $*$ \\
\hline Violet-green Swallow & & & & & & & & & & * & & & & & \\
\hline Barn Swallow & & & & & & & & & * & & & & & & $*$ \\
\hline Common Raven & $*$ & $\mathrm{~B}$ & B & & & & $*$ & & * & * & * & $*$ & & * & \\
\hline Ruby-crowned Kinglet & & & & & & & & & & & & & & $*$ & \\
\hline Northern Wheatear & B & & & & & & B & & & & & & $*$ & & $*$ \\
\hline Varied Thrush & & & & & & & * & & & & & & & & \\
\hline Yellow Wagtail & & & & & & & & & & $*$ & & & & & \\
\hline American Pipit & B & $*$ & $*$ & $*$ & $*$ & $*$ & $*$ & $*$ & $\mathrm{~B}$ & B & $*$ & $*$ & $*$ & B & $\mathrm{B}$ \\
\hline Yellow-rumped Warbler & & & & & & & & & & & & & & & $*$ \\
\hline
\end{tabular}


TABLE 4. Summary of bird observations on northern Coats Island, by year: * = observed, B = evidence of breeding - continued:

\begin{tabular}{|c|c|c|c|c|c|c|c|c|c|c|c|c|c|c|c|}
\hline & 1975 & 1981 & 1984 & 1985 & 1986 & 1987 & 1988 & 1989 & 1990 & 1991 & 1992 & 1993 & 1994 & 1995 & 1996 \\
\hline Chipping Sparrow & & & & & & & & & & $*$ & & & & & \\
\hline White-throated Sparrow & $*$ & & & & & & & & & & & & & & \\
\hline White-crowned Sparrow & & & & & & & & & & & & & $*$ & & \\
\hline Dark-eyed Junco & & & & & & & & & $*$ & & & & & & * \\
\hline Lapland Longspur & B & $*$ & & * & $*$ & $*$ & $*$ & * & $*$ & $*$ & $*$ & B & B & $*$ & $*$ \\
\hline Snow Bunting & B & $*$ & $*$ & $*$ & $*$ & $*$ & $*$ & * & B & B & B & B & B & B & B \\
\hline Red-winged Blackbird & & & & & & & & & * & & & & & & \\
\hline Rusty Blackbird & & & & & & & & & & & & & & & $*$ \\
\hline Yellow-headed Blackbird & & & & & & & $*$ & & & & & & & & \\
\hline White-winged Crossbill & & & & & & & & & & & & & $*$ & & \\
\hline Redpoll spp. & $*$ & & & $*$ & & & & & $*$ & $*$ & $*$ & $*$ & $*$ & $*$ & \\
\hline Pine Siskin & $*$ & & & * & & & & * & & & $*$ & & & $*$ & \\
\hline
\end{tabular}

Canada geese were widespread and abundant over the whole island in 1983 (Gaston et al., 1986).

Green-winged Teal Anas crecca: C. PEMBROKE: Two were seen on a pond $3 \mathrm{~km}$ west of camp on 4 July 1995 .

Black Duck Anas rubripes: C. PEMBROKE: Three were observed near camp on 12 August 1984.

Northern Pintail Anas acuta: CAIRN COVE: A female with three ducklings was seen on 22 July 1975. C. PEMBROKE: A female with two well-grown ducklings was near the HBC post on 28 August 1995. Parties of three on 31 May and four on 15 June 1996 were seen near camp. WEST HUT: Four were seen on shore on 15 July 1994, and eight males were in a tidal pool on 7 July 1995.

Common Eider Somateria mollissima: CAIRN COVE: Up to 300 were seen, including 75 ducklings. Two nests were found, one on 21 July (3 eggs) and one on 25 July 1975 (4 eggs). C. PEMBROKE: Small numbers were present on the sea in most years. In 1992, nests with three and four eggs were found on beerbottle beach on 14 July, and up to 50 birds were seen nearby on 4 August. In 1996, two nests, each containing five eggs, were found near the Cape Pembroke uglit on 19 July. Flocks of up to 40 were seen off Cape Pembroke and southwards along the coast in August of several years. WEST HUT: Up to 12 were on the sea in 1994; several pairs were present at the river mouth in 1995.

King Eider Somateria spectabilis: CAIRN COVE: Up to 15 were recorded, including a female with seven young and a group of six females with five young on 21 July 1975. C. PEMBROKE: Flocks of up to 50 females and young were seen offshore in all years, and pairs were seen on ponds in midway marsh in June of several years. Nests with eggs were found on upland tundra, well away from ponds (more than $200 \mathrm{~m}$ ), in July 1990 (1 nest), 1991 (1 nest), 1994 (1 nest), and 1995 (3 nests). WEST HUT: Two nests ( 3 and 5 eggs) were found on Dryas heath about $1 \mathrm{~km}$ from the sea and more than $100 \mathrm{~m}$ from the nearest pond.

Oldsquaw Clangula hyemalis: CAIRN COVE: Up to 200 were seen during 21-26 July 1975, including two broods of six ducklings and a nest with eight eggs. C. PEMBROKE: Birds were seen in most years on small ponds on upland tundra (less than 10 birds) and on the sea (usually less than 6 birds). In 1988, many were seen on ponds south of camp on 11 July, including some courting. A female with four young was seen on 7 August 1993 at midway marsh. Family groups (up to 12 ducklings) were recorded six times in 1994 within $2 \mathrm{~h}$ walk of camp. WEST HUT: About 30 drakes were present in the river mouth in 1993 and 1994 and more than 50 in 1995.

Black Scoter Melanitta nigra: C. PEMBROKE: Five were seen offshore on 5 August 1984.

White-winged Scoter Melanitta fusca: C. PEMBROKE: Two males and a female were present in the bay south of Cape Pembroke on 15 August 1981. One male was seen offshore of camp on 27-28 July 1987.

Red-breasted Merganser Mergus serrator: CAIRN COVE: Single birds were recorded on 22 and 25 July 1975. C. PEMBROKE: Singles or pairs were present on the sea on 1-4 days in 1989 and 1991-95. WEST HUT: Up to six drakes were present on the sea in 1995.

Rough-legged Hawk Buteo lagopus: C. PEMBROKE: One passed over camp high up on 27 May 1996.

Golden Eagle Aquila chrysaetos: There is a possible record of two seen in fall 1923 (Ford, in Sutton, 1932).

Peregrine Falcon Falco peregrinus: C. PEMBROKE: Birds were seen in all years in the camp area. Some were present at our arrival on 23 May 1990. At least eight sites were occupied during the period of our visits, although never more than four in the same year, and a maximum of three succeeded in rearing young. Table 5 gives details of occupation and reproductive success for five sites visited in several years. Of the other sites, two were occupied in only one year (airstrip beach in 1989 with two young; midway beach in 1996 with three young); both were close to the camp, and occupation would have been noted in every year, if they had been occupied. The years in which these sites were occupied were two of only three years in which no young were reared at the west colony site. In 1989, there was evidence that the same male was attending both the west colony and airstrip beach sites. The remaining site was situated about $1.5 \mathrm{~km}$ northeast of the gull colony and was visited in only one year, when three young were fledged. The site at the gull colony was also occupied in 1975. The site at beerbottle beach failed to rear any chicks until 1990, although occupied every year from 1984, when the female appeared to be immature. From 1990 to 1996 , however, the site was consistently successful. At the west colony, chicks fledged on 20 August 1990, about 20 August 1991, 23 August 1994, and about 23 August 1995. In 
TABLE 5. Summary of peregrine falcon site occupancy near Cape Pembroke, Coats Island.

\begin{tabular}{cccccc}
\hline \hline & $\begin{array}{c}\text { West } \\
\text { Colony (1) }\end{array}$ & $\begin{array}{c}\text { Beerbottle } \\
\text { Beach (2) }\end{array}$ & $\begin{array}{c}\text { Gull } \\
\text { colony (3) }\end{array}$ & $\begin{array}{c}\text { Cape } \\
\text { Pembroke (4) }\end{array}$ & $\begin{array}{c}\text { East } \\
\text { colony (5) }\end{array}$ \\
\hline 1981 & 3 y & 0 & $?$ & $?$ & $?$ \\
1984 & 3 y & PR & $?$ & $?$ & $?$ \\
1985 & 3 y & 0 & PR & $?$ & $?$ \\
1986 & 2 y & 0 & PR & $?$ & $?$ \\
1987 & 2 y & $?$ & $?$ & $?$ & $?$ \\
1988 & 3 y & 0 & PR & $?$ & PR \\
1989 & 0 y & 0 & $?$ & $?$ & $?$ \\
1990 & 1 y & 3 y & 0 & $?$ & $?$ \\
1991 & 1 y & 2 y & $?$ & 0 & $?$ \\
1992 & PR & PR & PR & $?$ & $?$ \\
1993 & 0 y & 3 y & $?$ & 1 y & $?$ \\
1994 & 2 y & 2 y & $?$ & $1+y$ & $?$ \\
1995 & 3 y & 2 y & PR & 0 & 0 \\
1996 & 0 y & 2 y & $?$ & 0 & 0 \\
\hline \hline
\end{tabular}

$\mathrm{PR}=$ pair present, outcome unknown; ? = not visited $0=$ pair not present; $0 \mathrm{y}, 1 \mathrm{y}, 2 \mathrm{y}$, etc. $=$ pair bred, with number of young fledged.

1996, chicks at the midway beach site fledged on 24 August. Prey remains at the west colony and beerbottle beach sites were examined in several years and consisted mainly of lapland longspurs and snow buntings, with a few ptarmigan and shorebirds, including adult white-rumped and semipalmated sandpipers, and American golden-plovers. In 1995, the remains of several thick-billed murres were present at the west colony site. Although peregrines were seen stooping at murres several times, sometimes hitting them, no actual kills were seen, except one bird knocked down on sea ice in June. The peregrine was quickly dispossessed by glaucous gulls. Usually, the thick-billed murres paid no attention to peregrines flying along the colony cliffs. WALRUS ISLAND: A nest contained three very small nestlings on 22 July 1993. It is hard to imagine that this small, barren island could support the pair. Presumably, they foraged on Southampton Island, $42 \mathrm{~km}$ distant, the nearest extensive land. HBC: Ford (in Sutton, 1932) reported them breeding at the murre colony, as they did in our time.

Gyrfalcon Falco rusticolus: C. PEMBROKE: Singles were seen near the west murre colony on 24 June 1992 (dark morph) and on four dates in June 1995 (light morph). J. Adamczewski (pers. comm. 1996) saw one in October 1982. HBC: Ford (in Sutton, 1932) reported that gyrfalcons fed on murres at the Coats Island colony "in fall."

Willow Ptarmigan Lagopus lagopus: CAIRN COVE: A female with five or six chicks was seen on 23 July 1975, and one male was collected (NMC 64839).

Rock Ptarmigan Lagopus mutus: CAIRN COVE: One or two were recorded on five dates during 21-27 July 1975. C. PEMBROKE: Pairs and small covies were common on rocky uplands in 1981, but subsequently there were relatively few sightings: two in 1986, including one family party on 27 July; in 1990, a covey of six in June and five other sightings near camp, including a nest with six eggs on 7 July that had eight eggs on 14 July; in 1991, a female on a nest with two eggs near midway marsh on 11 June, and two other records; in 1992, one sighting on 28 June; in 1993, a family of eight ( 1 female and 7 juveniles) near Cape Pembroke on 7 August; and in 1994, two singles near Cape Pembroke. There were no records in other years, nor were rock ptarmigan seen at the west hut. AERIAL SURVEYS: In 1983, "hundreds" were seen in well-vegetated areas around large lakes in the centre of the island. HBC: Ptarmigan hunting was reported only in September-December and in May, when they were described as "plentiful" in 1921. In the previous December, they were "many and very fat." Apparently many migrants arrived in fall; the earliest dates were 25 September and 7 October.

Sandhill Crane Grus canadensis: C. PEMBROKE: Several flew over camp on 8 and 10 June 1991; one was seen flying west over camp on 3 July and two on 16 August 1994; two flew west on 7 June and several flew over calling on 18 August 1996. WEST HUT: A pair was seen in 1995.

Black-bellied Plover Pluvialis squatarola: CAIRNCOVE: Up to 35 were seen, including three juveniles, on 21 July 1975. C. PEMBROKE: Two moulting adults were seen on 8 August 1991, and small numbers near camp following heavy snow on 21 and 27 June 1992. WEST HUT: At least 40 were seen in 1993, when several gave distraction displays; in 1994, 18 were seen, including one distraction display, but only two birds were seen in 1995 .

American Golden-Plover Pluvialis dominicus: CAIRN COVE: Up to 15 were seen on five dates during 21-27 July 1975. C. PEMBROKE: In 1992, up to six were seen frequently near camp in late June, then single birds were seen three times in July. Otherwise, there are only six records in 5 years, including one displaying near camp on 10 June 1991. WEST HUT: Two pairs, including one giving a distraction display, were seen on raised beaches $1 \mathrm{~km}$ inland in 1994. BENCAS ISLAND: Two were seen on 31 July 1995.

Semipalmated Plover Charadrius semipalmatus: CAIRN COVE: Up to 20 were seen, including an adult with chicks on 21 July 1975. C. PEMBROKE: This species was seen in all years, and evidence of breeding was obtained in 1985 (pair with young on 28 July), 1988 (pair with large chick on 11 August), 1991 (pair with two chicks on July 15), 1992 (distraction display, 27 July), and 1993 (pair with two flying young on 7 August at midway marsh. WEST HUT: They are common on beach ridges up to $1 \mathrm{~km}$ inland and were seen on all visits.

Greater Yellowlegs Tringa melanoleuca: C. PEMBROKE: One was seen flying over on 7 July 1992.

Whimbrel Numenius phaeopus: C. PEMBROKE: One to three were observed flying over camp during 18-20 August 1994 and two on 18 August 1996. WEST HUT: Sixty were seen in small parties along the shore in 1993, 13 flying in from the northwest on 15 July 1994, and one on the shore in 1995.

Ruddy Turnstone Arenaria interpres: CAIRN COVE: Four family groups were seen with two or three young each on 23 July 1975. C. PEMBROKE: One was seen flying over the beach on 8 June 1991 . They were seen frequently between 13 and 26 June 1992 close to camp on small, snow-free areas. WEST HUT: Very common, they were seen displaying in all years; one half-grown chick was seen in 1993. 
Red Knot Calidris canutus: CAIRN COVE: One was seen on 23 July and five on 25 July 1975. WEST HUT: One was seen with a party of black-bellied plovers on 31 July 1993.

Sanderling Calidris alba: CAIRN COVE: Up to 10 were seen on four dates during 21-27 July 1975.

Semipalmated Sandpiper Calidris pusilla: CAIRN COVE: Up to 20, including six family groups, were seen during 21-25 July 1975. C. PEMBROKE: One was seen near camp on 16-17 June and 20 at midway marsh on 18 June 1990; one was seen near camp on 31 May 1996. WEST HUT: Several in song flight and one three-quarter-grown chick were seen in 1993.

White-rumped Sandpiper Calidris fuscicollis: CAIRN COVE: Up to 30 were seen on three dates during 21 - 27 July 1975. C. PEMBROKE: Seen in 7 years, they were most numerous in 1992, when up to seven were seen daily near camp during 21-27 June. Breeding records: A family with half-grown chicks was seen on 24 July 1986; a pair apparently holding territory south of camp, on 2 July 1992; and a bird giving a distraction display, on 4 August 1993. WEST HUT: Here they were common in wet meadows and beside small ponds, mainly within $1 \mathrm{~km}$ of shore. In 1993, several gave the "rodent run" distraction display, and one was seen with two half-grown young.

Baird's Sandpiper Calidris bairdii: CAIRN COVE: Two family groups, including three downy young each, were seen on 23 July 1975. C. PEMBROKE: Single records occur in five years, including one family party seen on 24 July 1986. WEST HUT: Groups of up to 10 were common beside small pools just behind the shore, and broods of one and two almost full-grown chicks were seen in 1993, but none were recorded in 1994 and only one was seen in 1995.

Pectoral Sandpiper Calidris melanotos: CAIRN COVE: Two were seen on 23 July 1975. C. PEMBROKE: They were seen frequently near camp between 18 June and 2 July 1992. WEST HUT: About 20 pairs were scattered in an area of Dryas tundra c. $1 \mathrm{~km}$ inland, just southwest of Cape Prefontaine, in 1994; several gave distraction displays. In 1995 , one was seen between the main camp and west hut in upland heath.

Purple Sandpiper Calidris maritima: CAIRN COVE: Up to 75 were seen during $21-26$ July 1975 , including 14 family groups of two to four young, and one nest with four eggs. C. PEMBROKE: Sightings were recorded in most years on rocky uplands to the south of camp, usually solitary birds. Two family parties with half-grown young were seen in August 1986; a nest with three eggs was found on 23 June 1991 and had four eggs the next day; and in 1992, a brood of four chicks was seen on 29 July.

Dunlin Calidris alpina: CAIRN COVE: Up to 30 were seen during 21-25 July 1975, including four family groups of two young each. C. PEMBROKE: Seven were seen near camp on 9 June and c. 10 at midway marsh on 10 June 1990; we have three records of singles in 1992. WEST HUT: In 1993 , c. 15 were seen in an area of wet meadows and raised beaches about $1 \mathrm{~km}$ inland; only singles were seen in 1994 and 1995.
Stilt Sandpiper Calidris himantopus: C. PEMBROKE: One was seen on the beach on 7 June, and six at midway marsh on 18 June 1990.

Common Snipe Gallinago gallinago: C. PEMBROKE: One was observed on the west murre colony cliffs on 25 May 1990.

Red-necked Phalarope Phalaropus lobatus: CAIRN COVE: Three specimens were collected during 21-27 July 1975, including one immature bird; there was possible evidence of breeding. C. PEMBROKE: One was seen on 8 August 1991.

Red Phalarope Phalaropus fulicaria: CAIRN COVE: Up to 40 were seen during 21-27 July 1975. C. PEMBROKE: Two were seen on an ice pan near the west murre colony on 1 July 1991. WEST HUT: Many were present on pools and wet meadows up to about $1 \mathrm{~km}$ inland; in 1993, at least five pairs had young, ranging from a few days old to almost fully grown. In 1995 one male was flushed from a nest. BENCAS ISLAND: Several adults and one half-grown chick were seen on 31 July 1995.

Pomarine Jaeger Stercorarius pomarinus: CAIRNCOVE: Ten were seen on 25 July 1975, including one dark-morph bird. C. PEMBROKE: One subadult was seen on 14 June 1992.

Parasitic Jaeger Stercorarius parasiticus: CAIRNCOVE: Up to 25 were seen during 22-26 July 1975, including 4 out of $44(9 \%)$ dark-morph birds. C. PEMBROKE: Singles or pairs were seen occasionally in most years, and eight were seen flying over camp on 5 June 1996. Kleptoparasitic behaviour was observed on 2 August 1992, as a jaeger twice headed straight into an oncoming murre flock so that the flock broke up. The jaeger then chased one of the murres that was carrying a fish, until it broke away from the flock. In one case, the murre dropped its fish, which the jaeger retrieved; in the other, the murre dived into the ocean and the jaeger flew off. WEST HUT: Jaegers were common in all habitats in all years, but the only evidence of breeding was one pair giving a distraction display in 1994. Some were seen chasing terns carrying fish in 1993. All of the more than 50 seen during 1984-95 were pale morphs. BENCAS ISLAND: One was seen on 31 July 1995.

Long-tailed Jaeger Stercorarius longicaudus: CAIRN COVE: Three were seen on 21 July and seven on 25 July 1975. C. PEMBROKE: In 1991, two flew over land east of camp on 15 June and another on 25 July; a juvenile was seen in west colony cove on 6 August; in 1992, one was seen on 16 July and three on 24 August. Several were spotted at sea between Southampton and Coats Islands on 31 July 1992.

Bonaparte's Gull Larus philadelphia: C. PEMBROKE: One, looking bedraggled, appeared on the beach on 7 June 1990, after very strong winds.

Ring-billed Gull Larus delawarensis: C. PEMBROKE: One in second summer plumage was present on the beach with herring gulls on several days in 1981 .

Herring Gull Larus argentatus: CAIRN COVE: Up to 100 were seen, including five nests, three with chicks, during 21-26 July 1975. C. PEMBROKE: Small numbers (less than 
30) were seen in all years, mainly immatures; the earliest record was 28 May 1996. The herring gulls never approached the murre colony cliffs, but frequently fed in shallow water or roosted on the beaches. Numbers were generally highest in August. On 23 August, c. 50 flew eastward in parties of two and three, possibly in passage. WEST HUT: Several breeding colonies were found on small, sedge islands in large lakes (greater than 3 ha). In 1994, groups of 24, 7, and 4 nests were counted, as well as one solitary nest. At least ten broods 1015 days old were present in 1993, but in 1994 and 1995 all pairs were incubating. AERIAL SURVEYS: Herring gulls are common around the entire coast (Gaston et al., 1986).

Lesser Black-backed Gull Larus fuscus: C. PEMBROKE: One immature was seen near the west murre colony on 7 July 1991.

Great Black-backed Gull Larus marinus: CAIRN COVE: Two were seen on 23 July 1975. C. PEMBROKE: In 1992, two immatures and one adult frequented the west murre colony from 23 June to 4 July; in 1994, several immatures were present between 16 June and 9 July, after which only one immature in first-summer plumage remained. This gull was last seen on 14 August. In 1995, up to six immatures were seen on 10 dates in June and one on 23 August; in 1996, an adult was observed on 1 June and single immatures on 26 July and 12-13 August, the latter scavenging murre chick carcasses in the west colony cove. HBC: Ford (in Sutton, 1932) reported a "saddleback gull" near Cape Pembroke in 1923. Presumably, this was a great black-backed gull.

Iceland Gull Larus glaucoides: C. PEMBROKE: Small numbers of adults were seen foraging along the west murre colony in most years, taking murre eggs and chicks and discarded fish. A pair bred at the west colony in 1993, laying two eggs; the single chick was 1 week old on 3 August. Up to 150 were seen feeding close to shore along the north coast in August. Most of those seen, including all those in adult plumage, had the characteristics of the Kumlien's race $L$. glaucoides kumlieni, but several immatures resembling the Thayer's race L. glaucoides thayeri were also seen. A breeding colony of about 75 pairs was located on $70 \mathrm{~m}$ cliffs about $10 \mathrm{~km}$ south of camp and $1.5 \mathrm{~km}$ inland. This colony was reported by Smith (1966) as a Thayer's gull colony, but only one or two birds showing the dark wing tips of Thayer's were seen during our visits; the majority had the characteristics of Kumlien's. Further details are given by Gaston and Elliot (1990). No Iceland gulls were present at the colony in July 1975, when all gulls present appeared to be glaucous gulls.

Glaucous Gull Larus hyperboreus: CAIRN COVE: Up to 100 were seen during 21-26 July 1975 . At the gull colony referred to above, under Iceland gull, 106 nests were counted on 22 July, with approximately 175 adults and 75 young. C. PEMBROKE: Glaucous gulls were seen daily in all years. Between 11 and 16 pairs attempted to breed on large ledges among the murres at the west colony, and up to 3 pairs usually bred at the east colony. Hatching was observed accurately during 1990-92, when median dates were 2, 3, and 6 July. Earliest fledging was observed on 16 August in 1989 and on 5 August in 1994 (extremes). Mean numbers of eggs laid ranged from 2.4 in 1992 to 2.8 in 1994, and numbers of chicks reared ranged from 0.75/pair in 1990 to 2.27/pair in 1993. WEST HUT: A few were seen in all years, but there was no evidence of breeding. WALRUS ISLAND: Three pairs with chicks were seen on 22 July 1993. Bray (1943) reported nine pairs there in 1936.

Black-legged Kittiwake Rissa tridactyla: None were seen from the island or at sea. Ford (in Sutton, 1932) reports having seen the species at Coats Island, although the possibility of confusion with Sabine's Gull cannot be ruled out.

Sabine's Gull Xema sabini: C. PEMBROKE: One was seen on 14 June 1992. WEST HUT: Several small colonies were found on marshy islands in shallow ponds, one of them in the midst of a large colony of herring gulls. Four broods were seen in 1993: one of two small chicks, two of half-grown chicks ( 1 and 2), and one chick almost ready to fledge. In 1994, most pairs were incubating (13) and one had newly hatched chicks. In 1995, all nests were being incubated. BENCAS ISLAND: Several pairs were seen on 31 July 1995.

Arctic Tern Sterna paradisaea: CAIRN COVE: Up to 75 were seen during 21-27 July 1975, but no evidence of breeding was obtained there. C. PEMBROKE: No terns were recorded here. WEST HUT: Terns were common around ponds and lakes up to $2 \mathrm{~km}$ from the shore. Evidence of breeding was found in all years: two half-grown chicks in 1993; at least 30 pairs breeding within $3 \mathrm{~km}$ of west hut in 1994, including two nests with eggs, one pipping. In 1995, four pairs were incubating eggs. BENCAS ISLAND: Twentyfive pairs with partially grown chicks were observed on islands in a shallow pond, 31 July 1995.

Common Murre Uria aalge: One was present intermittently on the west murre colony from 12 July to 11 August 1990 and another was trapped and banded on 17 August 1996.

Thick-billed Murre Uria lomvia: The colonies at Coats Island have been estimated to support 33000 breeding pairs and to have increased by almost 100\% since 1972 (Gaston et al., 1993). Detailed breeding studies were carried out in 1988 and 1990-96, when median laying date ranged from 19 June in 1984 to 29 June in 1987. Birds were present around the island in all years at our arrival, including 1990, when first landfall on the cliffs must have been before 23 May. Main chick departures occurred between 10 and 25 August. Attendance at the colony occurred only during the night until the end of the first week of June. By 2 September 1995, the colony was completely deserted, except for a few dozen birds brooding very late chicks. For further details, see Gaston et al. (1994). HBC: Murres, always referred to as "tinkers," were present in the "thousands" on 6 May 1921. Men were sent to collect eggs each year, and in 1922, "lots of fresh eggs" were reported on 30 June. On 14 September "millions of tinkers" were in the post cove; a surprising date, given our observations. Two birds were seen on 18 February 1921, showing that small numbers winter in northern Hudson Bay; Sutton (1932) reported the same at Southampton Island.

Dovekie Alle alle: This species was not seen by us, but was reported by Ford (in Sutton, 1932) "rarely" near Cape Pembroke. 
Black Guillemot Cepphus grylle: CAIRN COVE: Up to 50 were seen during 21-26 July 1975. C. PEMBROKE: Small numbers were seen in all years between the west murre colony and Cape Pembroke and south along the coast as far as the Hudson's Bay post cove. Probably about 100 pairs breed along that stretch of coast. On 24 August 1995, five active nest sites were inspected near Cape Pembroke: two contained eggs (one pipped), one had two 7 to 10-day chicks, and two were inaccessible. Five adults were seen carrying large $(150 \mathrm{~mm})$ sand lances Ammodytes sp. Another two adults were seen carrying sand lances further south on 28 August. WALRUS ISLAND: Twenty nests, all with two eggs, were found on 22 July 1993 . About 150 adults were present in the vicinity of the island. BENCAS ISLAND: Several guillemots were present on a small, freshwater lake on 31 July 1995.

Atlantic Puffin Fratercula arctica: One was reported at sea between Coats and Southampton Islands in early August 1996 (J. Nakoolak, pers. comm. 1996).

Snowy Owl Nyctea scandiaca: CAIRN COVE: A partial skeleton was found near a fox den in July 1975. C. PEMBROKE: One was seen plucking a murre on the sea ice on 30 May 1990, one south of camp on 7 July 1992, and one near camp on 11 June 1995. SOUTH END: One was seen in late October 1983 (J. Adamczewski, pers. comm. 1996).

Short-eared Owl Asio flammeus: One flying over the west murre colony on 3 June 1996 caused many murres to leave their sites.

Horned Lark Eremophila alpestris: CAIRN COVE: One or two were seen on five dates in July 1975. C. PEMBROKE: Small numbers were seen in most years on rocky uplands. Broods of fledged young were seen on 28 July 1985, 6 August 1986, and 24 August 1995 (2 broods).

Violet-green Swallow Tachycineta thalassina: C. PEMBROKE: One was seen flying near camp and the west murre colony, landing occasionally on a rock cairn, on 3 July 1991.

Barn Swallow Hirundo rustica: C. PEMBROKE: One was seen hawking over landing strip beach on 23 May 1990, and one perched on the cabin roof on 10 June 1996.

Common Raven Corvus corax: CAIRN COVE: Singles were seen on two dates during 21-27 July 1975. C. PEMBROKE: Six were seen at the east murre colony on 14 August 1981, and five were present there on 9 August 1984; presumably both were family parties. In 1988, one visited the west colony on 21 June, and in 1991, one was seen on three days in early June. One or two were seen four times between 10 June and 4 August 1992. A dead adult was found near Cape Pembroke on 7 August 1993. One or two were seen near the west colony on eight dates in June 1995 and on 7 July. In 1996, singles were seen on 27 May, 1 June, and 10 August.

Ruby-crowned Kinglet Regulus calendula: One was seen near camp on 9-10 June 1995.

Northern Wheatear Oenanthe oenanthe: CAIRNCOVE: Three pairs with young were seen during 21-27 July 1975. C. PEMBROKE: A pair was feeding young at a nest near the gull colony on 22 July 1988, and one was seen near camp on
14-15 August the same year. Two were seen near camp on 26 July and one on 29 July 1994; in 1996, singles were seen on 15 and 21 June, and two juveniles were about $1 \mathrm{~km}$ south of camp on 27 July.

Varied Thrush Ixoreus naevius: C. PEMBROKE: A male was feeding in the centre of the west murre colony on 13 June 1988, after strong southwest winds on the previous day.

Yellow Wagtail Motacilla flava: C. PEMBROKE: One was seen near camp on 21 and 22 July 1991, after several stormy days.

American Pipit Anthus rubescens: CAIRN COVE: Up to 50, including a pair with dependent juveniles, were seen during 21-27 July 1975. C. PEMBROKE: Pipits were seen in all years, almost daily, with birds present at our arrival on 23 May in 1990. In 1988, recently fledged young were seen on 16 and 29 July, and in 1991, fledglings were seen being fed on 21 July. In 1992, up to four were seen regularly between 14 June and 18 July. Nests with eggs were found on 9 July 1995 and on 21 June 1996. Large numbers, obviously migrants, were present near camp on 5 September. WEST HUT: Here the species was uncommon, except on high, rocky ground.

Yellow-rumped Warbler Dendroica coronata: One was seen near the west murre colony on 9 June 1996.

Chipping Sparrow Spizella passerina: C. PEMBROKE: A single bird was seen near camp on 19 June 1991.

White-throated Sparrow Zonotrichia albicollis: CAIRN COVE: A singing male and a female were present on cliffs on 25 July 1975.

White-crowned Sparrow Zonotrichia leucophrys: C. PEMBROKE: A male was singing near camp on 18 June 1994.

Dark-eyed Junco Junco hyemalis: C. PEMBROKE: A single male was present around camp from 29 May to 7 June 1990, and another on 17 June 1996.

Lapland Longspur Calcarius lapponicus: CAIRNCOVE: Up to 65 , including several fledged broods, were seen during 21-27 July 1975. C. PEMBROKE: Sightings were recorded in all years except 1984 and 1987, with birds present at our arrival on 23 May in 1990. Up to 30 fed around camp during heavy snow in early June 1990; they were seen daily until 19 June, but rarely thereafter. Four were found dead on 15 June 1992, after a storm; they had no fat reserves, and their pectoral muscles appeared wasted. Breeding took place only on areas of grassy tundra, and the species was absent from the rocky uplands during the breeding season. Birds were usually seen around camp in small numbers from mid-August onwards. In 1995, flocks up to 15 occurred in late August, but none was seen after 5 September. WEST HUT: Sightings were common in all years on well-vegetated lowland tundra. Fledglings were seen in 1993, and adults carrying food, as well as a nest with four eggs, in 1994.

Snow Bunting Plectrophenax nivalis: CAIRN COVE: Many fledged broods were seen during 21-27 July 1975. C. PEMBROKE: Buntings were common and seen daily in all years. Large flocks (more than 30) occurred in late May and early June in some years. The first fledged brood was seen on 10 July in 1988, 20 July in 1991, 26 July in 1993, 8 August 
in 1994, and 26 July in 1996. A nest with five eggs was found on 1 July 1990 and had c. 5-day chicks on 17 July; another, with three eggs was found on 18 July 1992 . Flocks of up to 40 were seen near camp in most years after the first week of August, with more than 100 present in late August and dozens still about on 9 September in 1995. WEST HUT: Birds were common on dry uplands with rock outcrops: two broods of fledglings were being fed on 16 July 1993. HBC: Dates of first arrival of "snow birds" were recorded as 3 April 1920, 10 April 1922, and 13 April 1924. These compare with 30 March and 6 April for the Coral Harbour post in 1925 and 1926.

Red-winged Blackbird Agelaius phoeniceus: C. PEMBROKE: One male was singing lustily in camp on 8-12 June 1990.

Rusty Blackbird Euphagus carolinus: One male was present and singing near the west murre colony from 9 June to 26 July 1996.

Yellow-headed Blackbird Xanthocephalus xanthocephalus: C. PEMBROKE: One was present on the west murre colony from 13 to 30 June 1988, often feeding among the murres.

White-winged Crossbill Loxia leucoptera: C. PEMBROKE: One male was seen feeding among moss along the top of the west murre colony on 21 June 1994.

Redpoll Carduelis spp.: CAIRN COVE: One $C$. flammea was seen on 21 July 1975. C. PEMBROKE: Redpolls were seen in 7 years, but usually only once or twice a year and sometimes only in flight. A male on the west colony cliffs on 24 May 1990 and two seen in July 1992 all appeared to be common redpolls $C$. flammea. Up to four presumed passage migrants were seen or heard on seven dates from 28 August 1995. A flock of 12 seen on 29 May 1996 included individuals similar in plumage to both $C$. flammea and C. hornemanni. The latter species is shown by Godfrey (1986) as breeding on Southampton Island.

Pine Siskin Carduelis pinus: CAIRN COVE: A female was collected on 25 July 1975 (NMC 64893). C. PEMBROKE: One was heard on 3 August 1985, two were seen on 12 August 1989, and one circled camp twice on 30 July 1992. In 1995, singles were seen on 25 and 30 June and 2 August.

\section{DISCUSSION}

The mammals and birds of Coats Island are, not unexpectedly, very similar to those of Southampton Island to the north, which forms an intermediate stepping-stone between Coats Island and the mainland of Keewatin and which falls in the same ecoregion. The birds, and to a lesser extent the mammals, of Southampton Island have been well documented by Sutton (1932), Bray (1943), Parker and Ross (1973), and Abraham and Ankney (1986). The main differences between the two islands are the much lower numbers of geese on Coats Island, especially the lack of breeding snow geese, and the absence of lemmings or hares. The absence of small herbivorous mammals presumably determines the absence or rarity of their normal suite of predators: ermine, snowy owl, long-tailed and pomarine jaegers, gyrfalcon, and roughlegged hawk, all of which are found breeding on Southampton Island. In addition, ravens appear to be only sporadic breeders at Coats Island, which may also be related to the absence of lemmings.

That there was no mention of hares in the Hudson's Bay Company records suggests that they were never present on the island in recent times. Lemmings are not mentioned either, although, as they had no commercial or dietary value, they might not have been considered worthy of note. However, the persistently low fox harvests at Coats suggest that lemmings may also have been absent in the 1920s. The absence of these two small mammals illustrates the importance of the barrier to dispersal presented by the waters of Evans and Fisher Straits. The pack ice in these straits remains mobile throughout the winter and is considered sufficiently unpredictable to preclude travel by dogsled or snowmobile between Southampton and Coats Islands. However, if the tracks recorded in the Hudson's Bay Company journals were correctly identified, both wolf and lynx succeeded in crossing in the 1920s. The two sightings of red fox may also demonstrate winter dispersal across ice, although the presence of a small permanent population cannot be ruled out. Red foxes seem to be prone to wander long distances over sea ice, as attested by their dispersal across Hudson Strait and subsequent crossing of Lancaster Sound in the early 20th century (MacPherson, 1964). Wolves were extirpated from Southampton Island in the 1940s and have only just reimmigrated (1994-95, T. Devine, pers. comm. 1995), so it is not surprising that we saw no sign of them on Coats Island during our visits.

Our observations of bowhead whales, with only two seen, suggest that numbers are much reduced compared to the 1920 s, when sightings at Coats Island seem to have been more frequent, and several were killed off Southampton Island (Sutton and Hamilton, 1932). Other marine mammals appear to be similar in status now to the period of the HBC post, although it is hard to judge from the fragmentary journal reports. Apparently Coats Island was considered inferior for seal hunting to the south coast of Baffin Island, from where some of the Inuit had come. In the winters, most of the dogs starved, because insufficient seal meat was obtained. On the other hand, caribou seem to have been plentiful, although seldom reported near the HBC post: most are referred to as shot on hunting trips of several days. This appears to be similar to the situation today, when only small numbers occur at the northeast corner of the island. Most hunting parties from Coral Harbour that visited Coats Island for caribou in the 1980s concentrated on the west coast of the island, which was where the last resident Inuit families wintered.

Many of our bird records were of vagrants, which were hundreds, in some cases thousands, of kilometres from their breeding ranges. These include species not reported previously from northern Hudson Bay: great blue heron, black scoter, common snipe, Bonaparte's gull, lesser black-backed gull, ring-billed gull, common murre, short-eared owl, violetgreen swallow, varied thrush, yellow wagtail, ruby-crowned 
kinglet, chipping sparrow, rusty blackbird, yellow-headed blackbird, white-winged crossbill, pine siskin. The number of vagrants seems high in comparison with other stations in northern Hudson Bay and Foxe Basin (e.g., Sutton, 1932; Savile, 1950; MacPherson and McLaren, 1959; Ellis and Evans, 1960; Hohn, 1968; Parker and Ross, 1973; Renaud et al., 1981; Montgomerie et al., 1983; Gaston et al., 1985; Abraham and Ankney, 1986) and the difference seems too great to be accounted for only on the basis of the length of observations. It is possible that the well-vegetated area around the murre colonies attracts and concentrates off-course passerines, compared to the rather homogenous terrain covering most of Coats Island. A surprising number of the vagrants were seen on the densely grass-covered slopes above the west murre colony (great blue heron, common snipe, varied thrush, ruby-crowned kinglet, rusty blackbird, yellow-headed blackbird, dark-eyed junco, and white-winged crossbill).

A few bird species showed signs of population changes during our study. Great black-backed gulls, although recorded at Cairn Cove in 1975, were not recorded at all in the 1980 s, but were quite common by 1995 . This species has been expanding its population in Atlantic Canada and Hudson Bay. Conversely, rock ptarmigan, common in 1981, and seemingly abundant on the aerial survey in 1983, were very sporadic and definitely less common around camp in 199496 than in earlier years: more hiking in likely habitat was done in 1995 than in any other year. In the absence of lemmings and hares, with geese mainly passage migrants on the uplands, and with few caribou using the area, ptarmigan are the only vertebrate herbivores resident in the camp area. As the area supports good quantities of ericaceous heaths, conditions for ptarmigan seem ideal. However, four pairs of peregrine falcons within a few kilometres of one another may have had an impact on the local ptarmigan population.

The only species for which breeding records were obtained that are not shown as breeding on Coats Island by Godfrey (1986) were white-rumped and Baird's sandpipers, although the many sightings of red-breasted merganser suggest that they may also breed. The only species breeding in unusually high numbers were king eider, Sabine's gull (although densities appear similar to those reported for East Bay, Southampton Island by Abraham and Ankney [1984]), and purple and pectoral sandpipers, all of which appear to be distributed at very low densities throughout most of their breeding ranges. Many species recorded as breeding on Coats Island by Godfrey (1986) were included on the basis of the Museum's 1975 records, then unpublished. This paper constitutes the first documented record of breeding for many such species (e.g., common and king eiders, cf. Finney and Abraham [1986]).

\section{ACKNOWLEDGEMENTS}

We would like to thank all those who assisted the CWS and NMNS studies at Coats Island: Karel Allard, Thomas Alogut,
David Andrews, Anton Berto, Gwyllim Blackburn, Kate Bredin, Don Croll, Leah de Forest, Sandra Dickman, Garry Donaldson, Dirk Draulans, Christine Eberl, Richard Elliot, Anthony Erskine, John Geale, Grant Gilchrist, Graeme Gissing, the late Bill Gunn, Ellen Hayakawa, Mark Hipfner, Coleen Hyslop, Gabriella Ibarguchi, Christine James, Sue Johnson, Kaj Kampp, Clint Kelly, Kara Lefevre, Bruce Lyon, Elizabeth McLaren, Josiah Nakoolak, David Noble, Marco Passeri, Luc Pelletier, Sophia Perin, Richard Poulin, Paul Prior, Christoph Rohner, Stephen Smith, Ilya Storm, Steven Wendt. We also thank Jan Adamczewski, Fred Bruemmer, and Al Loughrey for sending us notes and photographs from their Coats Island visits and Cormack Gates, Dick Harington, and Gerry Parker for answering questions about their own experiences. We are most grateful to Anne Morton, Maureen Dolyniuk, and Andrea Paci, archivists with the Hudson's Bay Company Archives, and to Roanne Mokhtar of the National Archives of Canada for assistance with gaining access to material on the Coats Island Hudson's Bay Company post. Peter Blancher, Hugh Boyd, Graham Cooch, and Austin Reed commented on the manuscript.

\section{REFERENCES}

ABRAHAM, K.F., and ANKNEY, C.D. 1984. Partitioning of foraging habitat by breeding Sabine's gulls and arctic terns. Wilson Bulletin 96:161-172.

ABRAHAM, K.F., and ANKNEY, C.D. 1986. Birds of East Bay, Southampton Island, Northwest Territories. Canadian FieldNaturalist 100:180-185.

ADAMCZEWSKI, J.Z., GATES, C.C., HUDSON, R.J., and PRICE, M.A. 1987. Seasonal changes in body composition of mature female caribou and calves (Rangifer tarandus groenlandicus) on an arctic island with limited winter resources. Canadian Journal of Zoology 65:1149-1157.

ADAMCZEWSKI, J.Z., GATES, C.C., SOUTAR, B.M., and PRICE, M.A. 1988. Limiting effects of snow on seasonal habitat use and diets of caribou (Rangifer tarandus groenlandicus) on Coats Island, Northwest Territories, Canada. Canadian Journal of Zoology 66:1986-1996.

ADAMCZEWSKI, J.Z., HUDSON, R.J., and GATES, C.C. 1993. Winter energy balance and activity of female caribou on Coats Island, Northwest Territories: The relative importance of foraging and body reserves. Canadian Journal of Zoology 71:12211229.

AMERICAN ORNITHOLOGISTS' UNION. 1983. Check-list of North American birds, 6th ed. Washington, D.C.: American Ornithologists' Union.

BANFIELD, A.W.F. 1974. The mammals of Canada. Toronto: University of Toronto Press.

BRAY, R.J.O. 1943. Notes on the birds of Southampton Island, Baffin Island and Melville Peninsula. Auk 60:504-536.

BRUEMMER, F. 1969. Southampton, Coats and Bencas Islands. North (July-August 1969):26-33.

DONALDSON, G., CHAPDELAINE G., and ANDREWS, J.D. 1995. Predation of thick-billed murres, Uria lomvia, at two breeding colonies by polar bears, Ursus maritimus, and walruses, Odobenus rosmarus. Canadian Field-Naturalist 109:112-115. 
DREDGE, L., and COWAN, W.R. 1989. Quaternary geology of the southwestern Canadian Shield. In: Fulton, R.J., ed. Quaternary geology of Canada and Greenland. Geological Survey of Canada, Geology of Canada, No. 1. 214-249.

ELLIS, D.V., and EVANS, J. 1960. Comments on the distribution and migration of birds in Foxe Basin, Northwest Territories. Canadian Field-Naturalist 74:59-70.

FINNEY, G., and ABRAHAM, K.F. 1986. Eiders of the eastern Canadian Arctic. In: Reid, A., ed. Eider ducks in Canada. Canadian Wildlife Service Report Series No. 47. 55-73.

GASTON, A.J., and ELLIOT, R.D. 1990. Kumlien's gull, Larus glaucoides kumlieni, on Coats Island, Northwest Territories. Canadian Field-Naturalist 104:477-479.

GASTON, A.J., CAIRNS, D.K., ELLIOT, R.D., and NOBLE, D.G. 1985. A natural history of Digges Sound. Canadian Wildlife Service Report Series No. 46.63 p.

GASTON, A.J., DECKER, R., COOCH, F.G., and REED, A. 1986. The distribution of larger species of birds breeding on the coasts of Foxe Basin and northern Hudson Bay, Canada. Arctic 39:285-298.

GASTON, A.J., DE FOREST, L.N., DONALDSON, G.D., and NOBLE, D.G. 1994. Population parameters of thick-billed murres at Coats Island, Northwest Territories, Canada. Condor 96:935-948.

GASTON, A.J., DE FOREST, L.N., GILCHRIST, G., and NETTLESHIP, D.N. 1993. Monitoring thick-billed murre populations at colonies in northern Hudson Bay, 1972-92. Canadian Wildlife Service Occasional Paper No. 80. 16 p.

GATES, C.C., ADAMCZEWSKI, J., and MULDERS, R. 1986. Population dynamics, winter ecology and social organization of Coats Island caribou. Arctic 39:216-222.

GILLETT, J.M. 1976. Plants of Coats Island, Hudson Bay, Keewatin District, Northwest Territories. Canadian Field-Naturalist 90:390-396.

GODFREY, W.E. 1986. The birds of Canada. Rev. ed. Ottawa: National Museums of Canada.

HARINGTON, C.R. 1965. Coats Island caribou survey. Canadian Wildlife Service Ms. Report No. 1420.

HBC (HUDSON'S BAY COMPANY). 1918-24. Post journals, 1918-1924. Reels HBC 1MA19. Available at Hudson's Bay Company Archives, Provincial Archives of Manitoba, 200 Vaughan Street, Winnipeg, Manitoba R3C 1T5, Canada.

HEYWOOD, W.W., and SANFORD, B.V. 1976. Geology of Southampton, Coats and Mansel Islands, District of Keewatin, Northwest Territories. Geological Survey of Canada Memoir No. 382. 35 p.

HÖHN, E.O. 1968. The birds of Chesterfield Inlet, District of Keewatin, N.W.T., Canada. Canadian Field-Naturalist 82:244262.

LANDS DIRECTORATE. 1984. Coats Island. Land use information series map J45. Ottawa: Environment Canada.

LOUGHREY, A.G. 1959. Preliminary investigations of the Atlantic walrus Odobenus rosmarus rosmarus (Linnaeus). Ottawa: Canadian Wildlife Service Ms. Report No. 795.

MACPHERSON, A., and McLAREN, I.A. 1959. Notes on the birds of southern Foxe Peninsula, Baffin Island, Northwest Territories. Canadian Field-Naturalist 73:63-81.
MANNING, T.H. 1967. A report on the transfer of barren ground caribou from Coats Island to Southampton Island, Northwest Territories. Ottawa: Canadian Wildlife Service Ms. Report No. 1143.

MANSFIELD, A.W., and ST. AUBIN, D.J. 1991. Distribution and abundance of the Atlantic walrus, Odobenus rosmarus rosmarus, in the Southampton Island - Coats Island region of northern Hudson Bay. Canadian Field-Naturalist 105:95-100.

MARKHAM, W.E. 1985. The ice cover. In: Martini, I.P., ed. Canadian inland seas. Amsterdam: Elsevier. 101-116.

MAXWELL, J.B. 1985. A climate overview of the Canadian inland seas. In: Martini, I.P., ed. Canadian inland seas. Amsterdam: Elsevier. 79-100.

MILLER, E.H. 1982. Herd organization and female threat behaviour in the Atlantic walruses Odobenus rosmarus rosmarus (L.). Mammalia 46:229-234.

MONROE, B.L., Jr., BANKS, R.C., FITZPATRICK, J.W., HOWELL, T.R., JOHNSON, N.K., OUELLET, H., REMSEN, J.V., Jr., and STORER, R.W. 1985. Thirty-fifth supplement to the American Ornithologists' Union Check-list of North American Birds. Auk 102:680-686.

MONROE, B.L., Jr., BANKS, R.C., FITZPATRICK, J.W., HOWELL, T.R., JOHNSON, N.K., OUELLET, H., REMSEN, J.V., Jr., and STORER, R.W. 1987. Thirty-sixth supplement to the American Ornithologists' Union Check-list of North American Birds. Auk 104:591-596.

MONROE, B.L., Jr., BANKS, R.C., FITZPATRICK, J.W., HOWELL, T.R., JOHNSON, N.K., OUELLET, H., REMSEN, J.V., Jr., and STORER, R.W. 1989. Thirty-seventh supplement to the American Ornithologists' Union Check-list of North American Birds. Auk 106:532-538.

MONROE, B.L., Jr., BANKS, R.C., FITZPATRICK, J.W., HOWELL, T.R., JOHNSON, N.K., OUELLET, H., REMSEN, J.V., Jr., and STORER, R.W. 1991. Thirty-eighth supplement to the American Ornithologists' Union Check-list of North American Birds. Auk 108:750-754.

MONROE, B.L., Jr., BANKS, R.C., FITZPATRICK, J.W., HOWELL, T.R., JOHNSON, N.K., OUELLET, H., REMSEN, J.V., Jr., and STORER, R.W. 1993. Thirty-ninth supplement to the American Ornithologists' Union Check-list of North American Birds. Auk 110:675-682.

MONROE, B.L., Jr., BANKS, R.C., FITZPATRICK, J.W., HOWELL, T.R., JOHNSON, N.K., OUELLET, H., REMSEN, J.V., Jr., and STORER, R.W. 1995. Fortieth supplement to the American Ornithologists' Union Check-list of North American Birds. Auk 112:819-830.

MONTGOMERIE, R.D., CARTAR, R.V., McLAUGHLIN, R.L., and LYON, B. 1983. Birds of Sarcpa Lake, Melville Peninsula, Northwest Territories: Breeding phenologies, densities and biogeography. Arctic 36:65-75.

PARKER, G.R., and ROSS, R.K. 1973. Notes on the birds of Southampton Island, Northwest Territories. Arctic 26:123129.

REEVES, R., MITCHELL, E., MANSFIELD, A., and McCLAUGHLIN, M. 1983. Distribution and migration of the bowhead whale, Balaena mysticetus, in the eastern North American Arctic. Arctic 36:5-64. 
RENAUD, W.E., JOHNSTON, W.G., and FINLEY, K.J. 1981. The avifauna of the Pond Inlet region, N.W.T. American Birds 35:132- 134 .

RICHARD, P.R. 1993. Status of the beluga, Delphinapterus leucas, in western and southern Hudson Bay. Canadian Field-Naturalist 107:524-532.

SAVILE, D.B.O. 1950. Bird observations at Chesterfield Inlet, Keewatin, in 1950. Canadian Field-Naturalist 65:145-157.

SHILTS, W.W. 1985. Glaciation of the Hudson Bay region. In: Martini, I.P., ed. Canadian inland seas. Amsterdam: Elsevier. $55-78$.
SMITH, N.G. 1966. Evolution of some arctic gulls (Larus): An experimental study of isolating mechanisms. American Ornithologists' Union Monograph No. 4. 99 p.

SUTTON, G.M. 1932. The birds of Southampton Island. Memoirs of the Carnegie Museum (Pittsburgh) 12, II, section 2.

SUTTON, G.M., and HAMILTON, W.J., Jr. 1932. The mammals of Southampton Island. Memoirs of the Carnegie Museum (Pittsburgh) 12, II, section 1. 111 p. 